\title{
Differences in the composition of organic aerosols between winter and summer in Beijing: a study by direct-infusion ultrahigh-resolution mass spectrometry
}

\author{
Sarah S. Steimer ${ }^{1,2, a}$, Daniel J. Patton ${ }^{1}$, Tuan V. Vu ${ }^{3}$, Marios Panagi ${ }^{4,5}$, Paul S. Monks ${ }^{6}$, Roy M. Harrison ${ }^{3,7}$, \\ Zoë L. Fleming ${ }^{4, b}$, Zongbo Shi ${ }^{3}$, and Markus Kalberer ${ }^{1,2}$ \\ ${ }^{1}$ Department of Chemistry, University of Cambridge, Cambridge, CB2 1EW, UK \\ ${ }^{2}$ Department of Environmental Sciences, University of Basel, 4056 Basel, Switzerland \\ ${ }^{3}$ Division of Environmental Health and Risk Management, School of Geography, Earth and Environmental Sciences, \\ University of Birmingham, Birmingham, B1 52TT, UK \\ ${ }^{4}$ National Centre for Atmospheric Science (NCAS), Department of Chemistry, University of Leicester, Leicester, UK \\ ${ }^{5}$ Department of Physics and Astronomy, Earth Observation Science Group, University of Leicester, Leicester, UK \\ ${ }^{6}$ Department of Chemistry, University of Leicester, Leicester, UK \\ ${ }^{7}$ Department of Environmental Sciences/Center of Excellence in Environmental Studies, King Abdulaziz University, \\ P.O. Box 80203, Jeddah, Saudi Arabia \\ a now at: Department of Environmental Science, Stockholm University, 10691 Stockholm, Sweden \\ ${ }^{b}$ now at: Center for Climate and Resilience Research (CR2), Departamento de Geofísica, Universidad de Chile, \\ Santiago, Chile
}

Correspondence: Sarah S. Steimer (sarah.steimer@aces.su.se)

Received: 31 October 2019 - Discussion started: 8 January 2020

Revised: 20 July 2020 - Accepted: 15 September 2020 - Published: 10 November 2020

\begin{abstract}
This study investigates the chemical composition of $\mathrm{PM}_{2.5}$ collected at a central location in Beijing, China, during winter 2016 and summer 2017. The samples were characterised using direct-infusion negative-nano-electrosprayionisation ultrahigh-resolution mass spectrometry to elucidate the composition and the potential primary and secondary sources of the organic fraction. The samples from the two seasons were compared with those from a road-tunnel site and an urban background site in Birmingham, UK, analysed in the course of an earlier study using the same method. There were strong differences in aerosol particle composition between the seasons, particularly regarding (poly-)aromatic compounds, which were strongly enhanced in winter, likely due to increased fossil fuel and biomass burning for heating. In addition to the seasonal differences, compositional differences between high- and low-pollution conditions were observed, with the contribution of sulfur-containing organic compounds strongly enhanced under high-pollution conditions. There was a correlation of the number of sulfur-
\end{abstract}

containing molecular formulae with the concentration of particulate sulfate, consistent with a particle-phase formation process.

\section{Introduction}

Ambient air pollution is of growing concern regarding its negative effect on public health, especially in low- and middle-income countries (Cohen et al., 2017; Hoek et al., 2013; Lelieveld et al., 2015). One of these countries is China, where rapid development has led to air pollution becoming a major environmental issue (Guan et al., 2016). Areas of strong industrial activity and rapid urbanisation are particularly impacted (Chan and Yao, 2008; Hu et al., 2014). Beijing, China's capital, has faced severe issues with air pollution in recent decades, with a particular impact of particulate pollution (Zhang et al., 2016). As a response to this problem, an international research collaboration, the Atmo- 
spheric Pollution and Human Health in a Chinese Megacity (APHH-Beijing) project, was launched in an effort to understand the emissions, processes and health effects of air pollution in Beijing (Shi et al., 2019). This improved scientific understanding will then feed into the development of efficient mitigation measures to improve air quality and reduce health impacts. As a central part of the project, two 1-month-long coordinated field campaigns were conducted at two sites, central Beijing and rural Pinggu, in NovemberDecember 2016 and May-June 2017.

Fine ambient particulate matter (PM) is the major air pollutant (Dockery et al., 1993; Pope III et al., 2002), estimated to cause about 3 million deaths per year (World Health Organization, 2016). About $20 \%-90 \%$ of the fine particle mass is organic (Jimenez et al., 2009; Kanakidou et al., 2005). Organic material in the atmosphere is highly complex, consisting of thousands of different compounds (Goldstein and Galbally, 2007). Ultrahigh-resolution mass spectrometry (UHRMS) analysers such as the Fourier transform ion cyclotron (FTICR) or the Orbitrap have a high mass resolving power and high mass accuracy. This allows for separation of 100 s to 1000 s of compounds within a relatively small mass range, usually $100-500 \mathrm{Da}$, even without further chromatographic separation (Nozière et al., 2015). Additionally, it is possible to assign molecular formulae to unknown compounds. Direct-infusion UHRMS has proven to be highly successful in assessing the chemical properties of ambient aerosols from a large variety of sampling locations, ranging from remote (e.g. Dzepina et al., 2015; Kourtchev et al., 2013) to rural (e.g. Schmitt-Kopplin et al., 2010; Wozniak et al., 2008) and urban (e.g. Giorio et al., 2019; Tao et al., 2014; Tong et al., 2016). Since it is possible to assign elemental compositions to unknown compounds, compounds containing heteroatoms such as sulfur and nitrogen can be unambiguously detected. This has for example been used for the study of organosulfates (Lin et al., 2012; Schmitt-Kopplin et al., 2010; Tao et al., 2014).

In this paper we investigate the chemical composition of the polar organic fraction of $\mathrm{PM}_{2.5}$ collected in central Beijing during the APHH-Beijing campaign. While the average annual contribution of organic matter $(\mathrm{OM})$ to $\mathrm{PM}_{2.5}$ in Beijing has decreased since the 2000s, it remains a major contributor (> 20\%) (Lang et al., 2017). The contribution of organic carbon to $\mathrm{PM}_{2.5}$ is usually highest during winter (He et al., 2001; Lin et al., 2009; Wang et al., 2015). There are numerous studies investigating the sources of $\mathrm{PM}_{2.5}$ in Beijing. Biomass burning, dust, coal combustion, vehicle emissions, cooking and the secondary products have all been identified as important sources of $\mathrm{PM}_{2.5}$ in Beijing (Lv et al., 2016), with varying importance for the different seasons (Yu et al., 2013; Zhang et al., 2013). Coal combustion for residential heating was often found to be the dominant source of $\mathrm{PM}_{2.5}$ during winter (Song et al., 2007; Zhang et al., 2017b), though some recent studies highlight traffic emissions as the winter main source (Gao et al., 2018; Zíková et al., 2016).
In our study, we are focussing on the differences in aerosol composition between summer and winter and the influence of high- vs. low-pollution conditions. The Beijing data are also compared with data from Birmingham, UK, to investigate differences in composition in comparison with European urban background samples as well as with samples which are strongly influenced by traffic emissions.

\section{Materials and method}

\subsection{Particle sampling and sample preparation}

As part of the APHH-Beijing campaign (Shi et al., 2019), a total of $67 \mathrm{PM}_{2.5}$ aerosol samples were collected over $23 \mathrm{~h}$ each on quartz microfiber filters $(20.3 \times 25.4 \mathrm{~cm}$, What$\operatorname{man}^{\mathrm{TM}}$, GE, USA) at the Institute of Atmospheric Physics (IAP), Chinese Academy of Sciences in Beijing, China, using a high volume sampler (HVS) (TE-6070VFC, Tisch Environmental, USA). This field site is an urban site located in a residential area between the fourth and third north ring roads of Beijing. In addition to the samples, several procedural blank filters were collected. After sampling, all filters were stored at $<-22{ }^{\circ} \mathrm{C}$ until analysis. Of these filters, 33 were sampled during winter from 9 November to 11 December 2016, and 34 were sampled during summer from 22 May to 24 June 2017. For the study presented here, we selected the five filters with the highest mass loading and the five filters with the lowest mass loading for winter and summer each. All of the filters with high mass loadings in winter were impacted by haze events, while this was only the case for two of the five filters with high mass loadings in summer (Shi et al., 2019). An overview of the selected filters and their respective mass loadings is given in Table S1 in the Supplement. From these 20 filters, filter punches $\left(1.8\right.$ or $\left.3.5 \mathrm{~cm}^{2}\right)$ were extracted three times in $5 \mathrm{~mL}$ methanol (Optima ${ }^{\circledR}$ LC/MS grade) by sonication. The samples were cooled in an ice water bath during the extraction process to prevent heating of the solvent. The combined extracts from the three rounds of sonication were first filtered using $0.45 \mu \mathrm{m}$ pore size filters (Supelco Iso-Disc ${ }^{\mathrm{TM}}$ filters PTFE-4-4, $\left.4 \mathrm{~mm} \times 0.45 \mu \mathrm{m}\right)$. After gentle evaporation under nitrogen $\left(\mathrm{N}_{2}\right)$ to about $1-2 \mathrm{~mL}$, the extracts were filtered a second time using $0.2 \mu \mathrm{m}$ pore size filters (Supelco Iso-Disc ${ }^{\mathrm{TM}}$ filters PTFE-4-2, $4 \mathrm{~mm} \times 0.2 \mu \mathrm{m}$ ) and evaporated further under $\mathrm{N}_{2}$ to volumes between $120 \mu \mathrm{L}$ and to $1.8 \mathrm{~mL}$. The volumes were adjusted so that the concentration of total particle mass in the extracts is approximately the same ( $\sim 1.0 \mu \mathrm{g} \mu \mathrm{L}^{-1}$ assuming complete solvation). In addition, one of the procedural blank filters was extracted using the same method as described above for each of the two seasons. The extracts were stored in the freezer for $1-2 \mathrm{~d}$ until mass spectrometry analysis. For the Birmingham samples, five $24 \mathrm{~h}$ HVS quartz fibre filters were collected form an urban background site and a road tunnel each and processed in a similar way as described above, although with only one fil- 
tration step. A more detailed description of these samples and their collection, analysis, and data processing can be found in Tong et al. (2016).

\subsection{Mass spectrometry measurement and data processing}

All mass spectrometry measurements were performed in direct-infusion, negative-ionisation mode using an ultrahighresolution LTQ Orbitrap Velos mass spectrometer (Thermo Fisher, Bremen, Germany) with a TriVersa NanoMate ${ }^{\circledR}$ chipbased electrospray ionisation source (Advion Biosciences, Ithaca NY, USA). The source parameters were set to an injection volume of $5.0 \mu \mathrm{L}$, an ionisation voltage of $-1.4 \mathrm{kV}$ and a back pressure of $0.7 \mathrm{psi}$. The capillary temperature was $200^{\circ} \mathrm{C}$. The mass spectrometer was routinely calibrated using a Pierce LTQ Velos ESI Positive Ion Calibration Solution and a Pierce ESI Negative Ion Calibration Solution (Thermo Scientific, Waltham, MA, USA). The mass accuracy of the instrument was below $1.5 \mathrm{ppm}$, which was regularly checked before the analysis. Mass spectra were collected in full scan mode over two different mass ranges: $m / z 100-650$ and $m / z$ 150-900, with a resolution of 100000 at $m / z 400$. For each sample and blank, three replicate measurements of $1 \mathrm{~min}$ each were carried out for the two different mass ranges.

Initial assignments of molecular composition were made using Xcalibur 2.2 software (Thermo Scientific). The following constraints were applied to both sample and blank mass spectra: the maximum number of molecular formula assignments per peak in the mass spectrum was 40 , and the mass tolerance was $\pm 5 \mathrm{ppm}$; the molecular formulae were assumed to contain only the following elements with the given number of atoms: $1 \leq{ }^{12} \mathrm{C} \leq 100,0 \leq{ }^{13} \mathrm{C} \leq 1$, $1 \leq{ }^{1} \mathrm{H} \leq 200,0 \leq{ }^{16} \mathrm{O} \leq 50,0 \leq{ }^{14} \mathrm{~N} \leq 5,0 \leq{ }^{32} \mathrm{~S} \leq 2$ and $0 \leq{ }^{34} \mathrm{~S} \leq 1$. The three repeat measurements of the blank filters for both high and low mass range were manually merged to yield four final blank files: low mass range winter, high mass range winter, low mass range summer and high mass range summer. Each of these merged blank files contains all masses from the three repeat measurements as separate data points. Data filtering was performed using Mathematica 11.2 (Wolfram Research Inc., UK) with a code package developed in-house (Zielinski et al., 2018). In the first instance, all ions below the noise level, which was estimated based on fitting a normal distribution to a histogram of intensities, were removed from the spectrum. As a second step, peaks in the sample that have a corresponding match in the blank with an intensity above a minimum sample-to-blank ratio of 10 were removed (blank subtraction). Based on the mass drift of 1215 reference compounds present in the sample, the maximum acceptable mass drift was set to the highest/lowest reference mass drift $\pm 0.5 \mathrm{ppm}$. All assignments based on mass drifts outside this range were discarded. Several additional rules were employed to remove chemically non-meaningful as- signments: all molecular formulae where $\mathrm{O} / \mathrm{C} \geq 2.0,0.3 \leq$ $\mathrm{H} / \mathrm{C} \geq 2.5, \mathrm{~N} / \mathrm{C} \geq 1.3$ and $\mathrm{S} / \mathrm{C} \geq 0.8$ were eliminated with the aim to remove compounds that are not likely to be observed in nature, as well as assignments without carbon, hydrogen or oxygen. Neutral formulae that had either a noninteger or a negative value of the double bond equivalent (DBE) were also removed from the list of possible molecules. Double bond equivalents were calculated using the following equation (McLafferty and Tureček, 1993):

$\mathrm{DBE}=x-\frac{1}{2} y+\frac{1}{2} z+1$,

with $\mathrm{I}_{y} \mathrm{II}_{n} \mathrm{III}_{z} \mathrm{IV}_{x}$, where I represents monovalent elements, II represents bivalent elements, III represents trivalent elements and IV represents tetravalent elements. Sulfur was assumed to be bivalent and nitrogen trivalent for this calculation. Assignments which fail the nitrogen rule (McLafferty and Tureček, 1993) were similarly removed. Elemental formulae containing ${ }^{13} \mathrm{C}$ or ${ }^{34} \mathrm{~S}$ were checked for the presence of their ${ }^{12} \mathrm{C}$ or ${ }^{32} \mathrm{~S}$ counterparts respectively. If there was no peak with a matching composition containing only the lighter isotope or if the intensity ratio of heavier-to-lighter isotope was greater than the natural isotopic abundance, the formula with the next larger mass error was used instead. The three repeated measurements for each sample and mass range were then combined into one file, keeping only ions present in all three replicates. The two mass ranges were then merged, resulting in one combined mass spectrum per sample. As a final step, the five samples taken for each of the four measurement conditions (winter high, WH; winter low, WL; summer high, $\mathrm{SH}$; and summer low, SL) were combined into a single mass spectrum for each of the four conditions. These mass spectra contain only ions present in all five samples analysed for the respective atmospheric condition, thus representing a typical chemical composition for WH, WL, SH and SL, respectively. With the exception of Sect. 3.3, the following discussion will only compare these four common ion spectra and not the 20 individual samples.

\subsection{Ion chromatography analysis}

A cut piece of $3 \mathrm{~cm}^{2}$ of theses filters and $10 \mathrm{~mL}$ deionised water $(18 \Omega)$ were added into a $15 \mathrm{~mL}$ polypropylene centrifuge tube. They were then sonicated using an ultrasonic bath with ice water for $1 \mathrm{~h}$ at a controlled temperature $\left(<20^{\circ} \mathrm{C}\right)$. Subsequently, the extract solution was shaken on a mechanical shaker for $3 \mathrm{~h}$ at approximately 60 cycles per minute. Water anion soluble ions $\left(\mathrm{SO}_{4}^{2-}, \mathrm{NO}_{3}^{-}\right)$in the filtered extract solution were analysed by ion chromatography (Dionex model ICS-1100). 


\subsection{Back trajectory modelling}

The Numerical Atmospheric-dispersion Modelling Environment (NAME, UK Met Office) (Jones et al., 2007) was used to track the pathways of air masses arriving in Beijing. A large number of hypothetical inert particles are released and their pathways are tracked backwards in time using meteorological fields from the UK Met Office's Unified Model with a horizontal grid resolution of $0.23^{\circ}$ longitude by $0.16^{\circ}$ latitude and 59 vertical levels up to an approximate height of $30 \mathrm{~km}$ (Brown et al., 2012). For this study, we modelled $3 \mathrm{~d}$ backward footprints with release periods that were the same time as the measurements (i.e 22/23 h). The output has a resolution of $0.25^{\circ} \times 0.25^{\circ}$ and represents the hypothetical inert particles passing through the surface layer (here defined as 0-100 $\mathrm{m}$ above ground) during their travel to the IAP meteorological tower in Beijing. The residence time the air masses spent over a specific location (Fig. 3) or region (Fig. S2 in the Supplement) during the four measurement conditions (WH, WL, SH, SL) was calculated by producing a summed plot of the NAME footprints from the five individual samples analysed for each measurement condition. More in-depth information about the origin of different air masses in Beijing, including time periods not covered by the APHH campaign, can be found in Panagi et al. (2020). They investigated the different origins of the air masses during a 4-year period and how this is correlated with $\mathrm{CO}$ levels and $\mathrm{CO}$ transportation to Beijing and calculated the residence times in air masses from four quadrants around the IAP tower in Beijing, finding many more north-westerly air masses in winter and southern air masses in summer.

\section{Results and discussion}

\subsection{Compositional overview}

The common ion mass spectra for the four atmospheric conditions are shown in Fig. 1, indicating that the vast majority of compounds above the detection limit are below $m / z 500$. While in winter almost no peaks are present with $\mathrm{m} / z>450$, a significant number of peaks up to $m / z 500$ are detected in the summer samples. The overall number of assigned formulae per sample ranged from 918 in the SL sample to 1586 in the WH sample. This is a lower limit on the total number of ionised compounds in the samples, as the technique cannot distinguish between structural isomers. Figure 2 shows the relative number contribution of the four different compound groups (CHO, CHON, CHOS, CHONS) to the total number of assigned formulae. ESI, like all ionisation methods for mass spectrometry, is not equally efficient in ionising different compounds, and the ionisation efficiency for one compound will differ between positive and negative mode. ESI works best for polar molecules, which is why pure hydrocarbons are usually not detected efficiently. A trend that
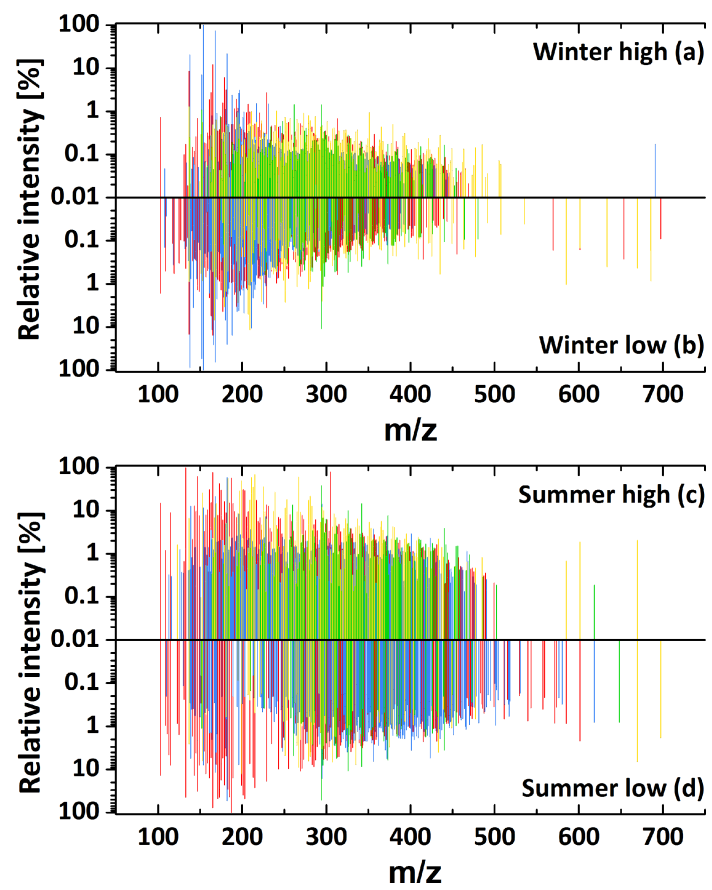

Figure 1. Negative-ionisation mass spectra for the four composite samples WH (a), WL (b), SH (c) and SL (d). Colour-coding differentiated formulae with differing molecular compositions: $\mathrm{CHO}$ (red), CHON (blue), CHOS (yellow) and CHONS (green).

can be seen in the detected formulae is the presence of significantly more CHON formulae in summer compared to winter. The opposite trend was observed in Shanghai by Wang et al. (2017a), who found higher numbers and relative contribution of CHON in winter. Further information would be needed to explain this discrepancy. Another seasonal difference is that significantly more sulfur-containing formulae (CHOS and CHONS) were observed for high-pollution conditions in both winter and summer. Overall, the highest percentage of sulfur-containing formulae was found under highpollution conditions in winter. Figure S1 shows the overlap of assigned formulae, divided into $\mathrm{CHO}, \mathrm{CHON}, \mathrm{CHOS}$ and CHONS, between the different samples. From this graph, it can be seen that the low mass loading samples (i.e. WL and SL) contain hardly any unique CHOS and CONS formulae above our detection limit. These results regarding the sulfurcontaining compounds are in good agreement with Jiang et al. (2016), who compared wintertime Beijing samples collected under hazy and clean conditions. A more detailed discussion of the sulfur- and nitrogen-containing compounds and their sources can be found in Sect. 3.3.

The strongly varying particle composition in winter and summer and during high- and low-pollution conditions is reflected by changes of the source regions during these four conditions. Back trajectories show that during strongly polluted days (WH, SH), air masses originate from south of Beijing, which is widely industrialised (Fig. 3). In contrast, 


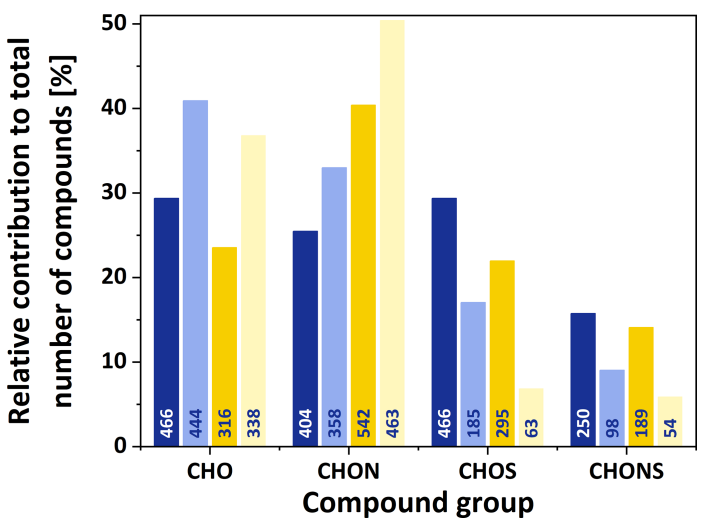

Figure 2. Bar charts showing the relative contribution of different compound groups ( $\mathrm{CHO}, \mathrm{CHON}, \mathrm{CHOS}, \mathrm{CHONS})$ to the total number of formulae for each of the composite samples: WH (dark blue), WL (light blue), SH (dark yellow) and SL (light yellow). The numbers on the bars indicate the absolute number of formulae detected for the respective sample and compound class.

days with low-pollution conditions in both seasons are characterised by more varied air mass histories. Especially during the collection of the WL samples, the air masses originated predominantly from the north-west (Fig. S2), a region including a less developed part of China as well as the only sparsely populated country Mongolia.

Average oxygen-to-carbon $(\mathrm{O} / \mathrm{C})$ and hydrogen-to-carbon $(\mathrm{H} / \mathrm{C})$ ratios for each sample set were calculated by dividing the total number of oxygen respective hydrogen atoms in all formulae in the data set by the total number of carbon atoms. The calculated ratios are shown in Table 1. The average $\mathrm{H} / \mathrm{C}$ ratios are lower in winter and in the Birmingham tunnel (BT) sample. This points towards the presence of more aromatic formulae, while the summer and the Birmingham background (BB) sample are more aliphatic. Aromatic compounds are predominantly produced from anthropogenic sources such as traffic, industry and heating (Baek et al., 1991; Hamilton and Lewis, 2003), whereas aliphatic compounds can be of both anthropogenic and biogenic origins, the latter of which are more prevalent in the summer (Gelencsér et al., 2007; Hu et al., 2017; Kleindienst et al., 2007). One type of source that will be present in both seasons and which contributes compounds of both high and low $\mathrm{H} / \mathrm{C}$ to particulate matter is vehicle emissions, as these are usually a mix of low carbon number $(<24)$ polycyclic aromatic hydrocarbons (PAHs) and single-ring aromatics with low $\mathrm{H} / \mathrm{C}$ and alkenes and cyclic, branched and straight-chain alkanes with high H/C (Gentner et al., 2012, 2017; Huang et al., 2015; May et al., 2014; Worton et al., 2014). The SL $\mathrm{H} / \mathrm{C}$ ratio is particularly high, which may be due to a larger proportion of primary biogenic organic aerosol components from plant sources with a high $\mathrm{H} / \mathrm{C}$, such as plant waxes, and a smaller influence of industrial sources or vehicle emissions, which is more pronounced in the high-pollution sample. In-
Table 1. Average $\mathrm{O} / \mathrm{C}$ and $\mathrm{H} / \mathrm{C}$ ratios for each sample set.

\begin{tabular}{lrr}
\hline Sample set & Average O/C & Average H/C \\
\hline Winter low (WL) & 0.41 & 1.19 \\
Winter high (WH) & 0.48 & 1.25 \\
Summer low (SL) & 0.54 & 1.53 \\
Summer high (SH) & 0.62 & 1.44 \\
Birmingham background (BB) & 0.54 & 1.44 \\
Birmingham tunnel (BT) & 0.42 & 1.16 \\
\hline
\end{tabular}

creased contribution of biogenic plant waxes to $\mathrm{PM}_{2.5}$ during summer in Beijing has been observed previously (Feng et al., 2005).

While the overall $\mathrm{H} / \mathrm{C}$ ratio shows whether the sample is more aromatic or aliphatic, the $\mathrm{O} / \mathrm{C}$ ratio gives an indication of how strongly oxidised a sample is. Table 1 shows that there are more highly oxidised formulae in the summer and the BB sample sets, which could be due to higher levels of photochemistry in the summer in Beijing, and at the Birmingham background site. The $\mathrm{O} / \mathrm{C}$ ratio is much lower in the winter and in the Birmingham tunnel sample. In Beijing, this could be due to reduced photochemistry in the winter months in Beijing, so that the particles are sampled before they can undergo atmospheric ageing processes, for example reacting with $\mathrm{OH}$ radicals and ozone. The average ozone concentrations at the IAP site during sample collection were $13 \mathrm{ppb}$ (WL), $6 \mathrm{ppb}(\mathrm{WH}), 39 \mathrm{ppb}(\mathrm{SL})$ and $63 \mathrm{ppb}(\mathrm{SH})$. In addition to ozone, the concentrations of other gas pollutants as well as temperature and humidity data for the different samples can be found in the Supplement in Table S2. For the BT sample, the lower $\mathrm{O} / \mathrm{C}$ ratio likely reflects a largely primary particle composition.

Van Krevelen diagrams, in which $\mathrm{H} / \mathrm{C}$ is plotted against $\mathrm{O} / \mathrm{C}$ for each assigned formula (Kim et al., 2003), are widely used as a means to categorise aerosol samples since they provide a clear representation of the range of $\mathrm{O} / \mathrm{C}$ ratios found in the organic aerosol sample (Nizkorodov et al., 2011). Van Krevelen plots for both the Beijing samples and the samples from Birmingham are shown in Fig. 4. It can be seen that for the winter samples, a lot of formulae are located in the aromatic region $(\mathrm{H} / \mathrm{C}<1, \mathrm{O} / \mathrm{C}<0.5)$ (Mazzoleni et al., 2012) and that there is a significant reduction of formulae in this region in the summer data. This aromatic region is also strongly populated in the BT sample. The SL period is nearly devoid of formulae in the aromatic region, while the aromatic region of SH is similar to the $\mathrm{BB}$ sample, which was recorded in early autumn. These observations about aromaticity are in agreement with the conclusions drawn from the total $\mathrm{H} / \mathrm{C}$ ratio. The formulae that can be identified as aromatic tend to be $\mathrm{CHO}$ and CHON. Conversely, CHOS and CHONS formulae are primarily located outside of this aromatic region, with much higher $\mathrm{H} / \mathrm{C}$ ratios, indicating a lower level of aromaticity. Figure 4 shows that there is a visible increase in not just the percentage of sulfur-containing formulae (see Fig. 2), but 

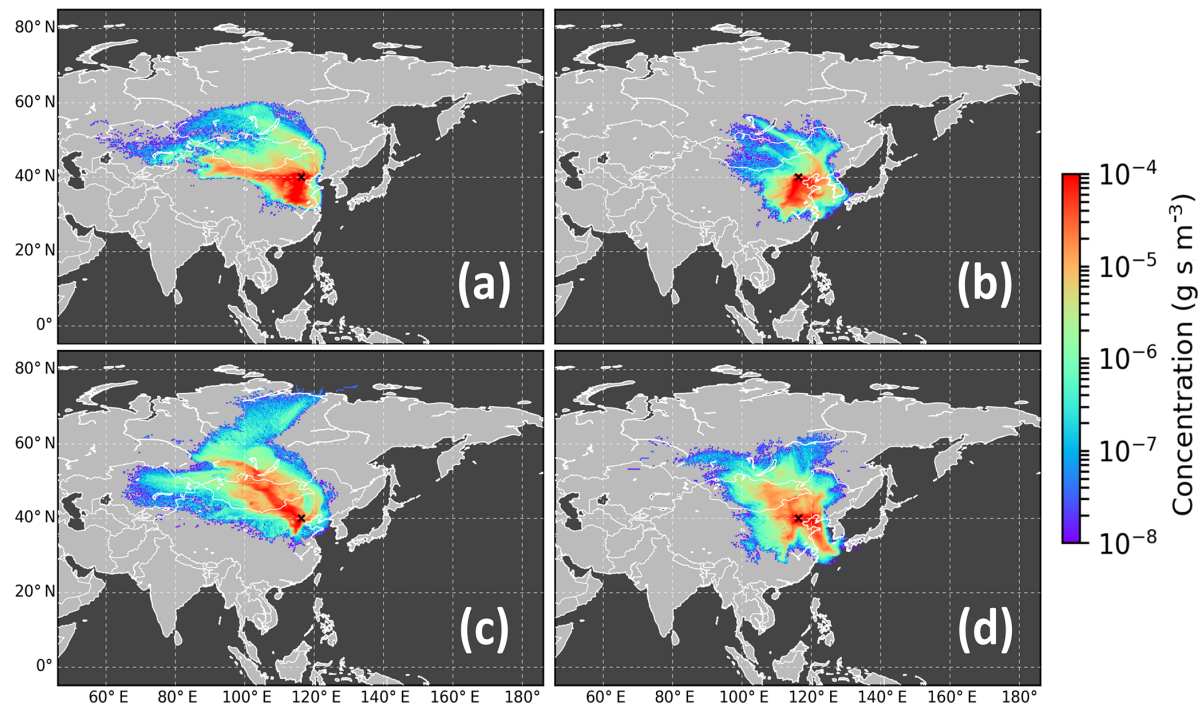

Figure 3. Sum of the $72 \mathrm{~h}$ back trajectories for (a) winter, high-pollution days (WH), (b) summer, high-pollution days (SH), (c) winter, lowpollution days (WL), and (d) summer, low-pollution days (SL). The colours denote the relative (on a logarithmic scale) residence time of the air masses in each $0.25^{\circ} \times 0.25^{\circ}$ grid box (up to $100 \mathrm{~m}$ from the surface) during the last $72 \mathrm{~h}$ before arriving at the monitoring station (the model calculates the concentration of theoretical air mass particles integrated over time per volume). The black cross denotes the sampling location.

also the absolute number of sulfurous formulae in $\mathrm{WH}$ over WL. A similar trend can be seen for the summer.

\subsection{Aromatic compounds}

The low $\mathrm{H} / \mathrm{C}$ ratios for several of the samples suggest the presence of a large number of aromatic compounds. Figure 5 shows a Van Krevelen plot for the different samples in which the different formulae are colour mapped according to their double bond equivalent (DBE), which was calculated according to Eq. (1). The DBE gives the number of double bonds plus rings in a molecule. For DBE calculations, it is usually assumed that all atoms involved (except hydrogen) obey the octet rule. While this assumption tends to hold true in strictly reducing environments, under oxic conditions, such as in the atmosphere, it is likely that both sulfur and nitrogen compounds with higher valency are present. Such compounds for example include organosulfates or organonitrates and nitro compounds, which are frequently detected in ambient particles. The DBE values calculated here therefore represent a lower limit. A high DBE indicates likely aromaticity of a compound. It can be seen that the region identified in Fig. 4 as containing most likely aromatic compounds contains the formulae with the highest DBE. The smallest PAH, naphthalene, has a DBE of 7; thus all formulae in Fig. 5 shown in yellow, red or brown colours are probably polycyclic aromatics, likely oxidised PAHs. This assumption is corroborated by the findings of Elzein et al. (2019), who used gas chromatography-time-of-flight mass spectrometry to quantify the concentration of 10 oxygenated PAHs (OPAHs) and 9 nitrated PAHs (NPAHs) during the APHH winter campaign and found the total concentration of OPAHs to range from 1.8 to $95.5 \mathrm{ng} \mathrm{m}^{-3}$ and that of NPAHs from 0.13 to $6.43 \mathrm{ng} \mathrm{m}^{-3}$.

The DBE values of the molecules found in the aromatic region for $\mathrm{WH}$ and $\mathrm{WL}$ exceed that of the sample from BT. This suggests that larger polycyclic aromatics are found in Beijing air in the winter than in aerosol collected in a road tunnel in a European city, likely due to an increase in solid fuel burning for residential heating. A general increase in the concentration of PAHs and oxidised PAHs in China during winter, generally attributed to residential heating, has been observed in multiple studies (Bandowe et al., 2014). In addition to this, Zhang et al. (2017) found a sharp increase in the concentration of higher-ring-number $(\geq 4)$ PAHs at the start of the heating season and Huang et al. (2014) observed a similar increase in emission of higher-ring-number PAHs for coal combustion compared to gasoline and diesel, lending weight to our hypothesis about the origin of the larger polycyclic aromatics.

While the DBE can be used to determine the number of C$\mathrm{C}$ double bonds in pure hydrocarbons, heteroatoms present in a compound can form double bonds not contributing to aromaticity, ring formation or condensation (Koch and Dittmar, 2006). To overcome this problem associated with DBE another parameter has been developed, the aromaticity equivalent $(\mathrm{Xc})$. For organic molecules containing only oxygen and/or nitrogen, the aromaticity equivalent can be calculated as follows (Yassine et al., 2014):

$$
\mathrm{Xc}=\frac{2 \mathrm{C}+\mathrm{N}-\mathrm{H}-2 m \mathrm{O}}{\mathrm{DBE}-m \mathrm{O}}+1,
$$



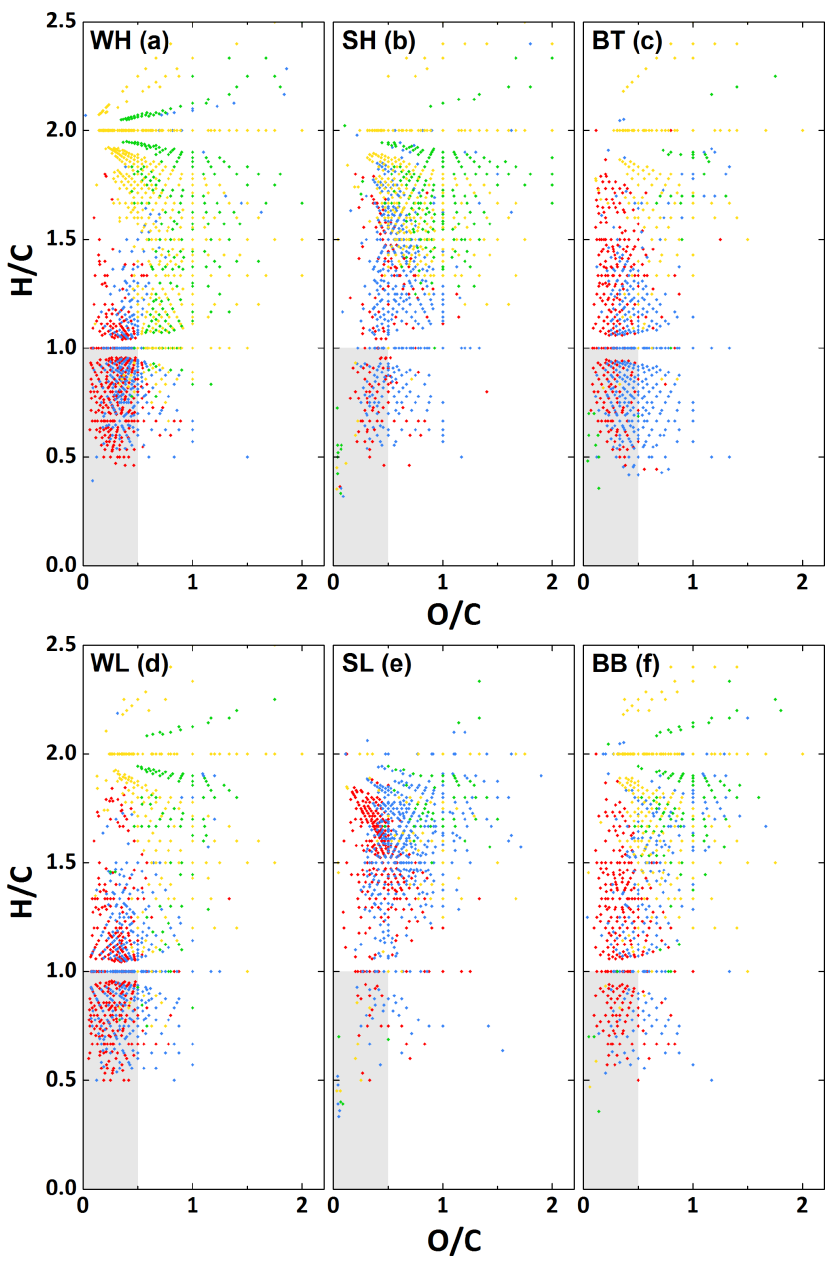

Figure 4. Van Krevelen plot for the WH, WL, SH, SL, BT and BB sample sets. The colours denote the $\mathrm{CHO}$ (red), $\mathrm{CHON}$ (blue), CHOS (yellow) and CHONS (green) formulae detected for each sample set. The aromatic region is shaded in grey.

where $\mathrm{C}, \mathrm{N}, \mathrm{H}$ and $\mathrm{O}$ are the number of carbon, nitrogen, hydrogen and oxygen atoms respectively, and $m$ is the fraction of oxygen atoms involved in the $\pi$-bond structure of the compound which differs for different functional groups. For carboxylic acids, esters and nitro functional groups $m=$ 0.5 . Since the measurements in this study were performed with electrospray ionisation in negative mode, carboxylic acids likely dominate the signal so $m=0.5$ is presumed for the calculation of Xc. Organic peroxy compounds can account for a significant fraction of organic particulate matter. For these compounds $m$ is $<0.5$, as less than half of the oxygen atoms are involved in a $\pi$-bond structure. If our samples were to contain a large number of peroxy compounds, we would be underestimating the degree of unsaturation in the sample. The same is true if most of the of nitrogen-containing compounds are organonitrates rather than nitro compounds. The values should therefore be considered a conservative estimate. If $\mathrm{DBE} \leq m \mathrm{O}$, then $\mathrm{Xc}=0$.

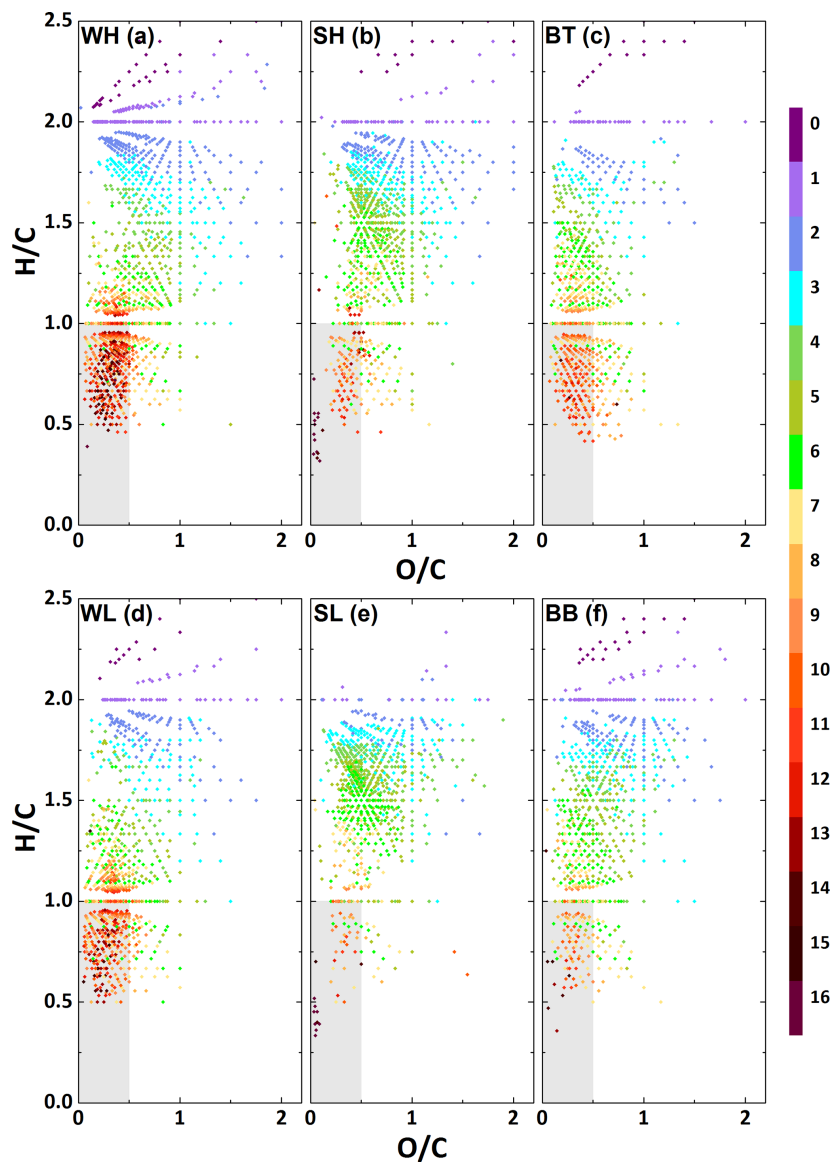

Figure 5. Van Krevelen plot for the WH, WL, SH, SL, BT and BB sample sets. Colour indicates the double bond equivalent (DBE), calculated under the assumption that sulfur is bivalent. The aromatic region is shaded in grey.

Compounds with $\mathrm{Xc} \leq 2.5000$ are non-aromatic, for monocyclic aromatics $2.5000 \leq \mathrm{Xc} \leq 2.7143$ and for polycyclic aromatics $X c \geq 2.7143$. There are too many possible oxidation states of sulfur to correctly assign the aromaticity of the CHOS and CHONS compounds, and so this characteristic was not investigated further for S-containing formulae.

The distribution of polycyclic, monocyclic aromatics and aliphatic formulae on a Van Krevelen plot for all samples is shown in Fig. 6. The vast majority of polycyclic aromatics can be found in the region outlined before as aromatic $(\mathrm{H} / \mathrm{C}<1, \mathrm{O} / \mathrm{C}<0.5)$; however, some have slightly higher $\mathrm{H} / \mathrm{C}$ ratios, which may be due to extended alkyl chains as the $\mathrm{H} / \mathrm{C}$ cut-off does not account for this. The majority of monocyclic aromatics are found outside the aromatic region, which indicates that the majority of them contain long alkyl chains. Molecules classified as non-aromatic are found entirely outside of the previously defined aromatic region, as expected. The calculated Xc values confirm that the summer samples have many fewer aromatic formulae than the winter samples. The SL sample is particularly low in aromatic for- 
mulae (132 aromatic formulae vs. 801 in total), especially regarding polycyclic aromatics (26 formulae). In contrast, there are a reasonable number of polycyclic (85) and monocyclic (159) aromatics in SH. The two winter samples both show high contributions of aromatic formulae (76\% in WH vs. $77 \%$ in $\mathrm{WL}$ of all detected formulae in these samples). However, the WH sample is strongly dominated by polycyclic aromatics with 403 polycyclic vs. 260 monocyclic aromatic formulae, while monocyclic and polycyclic aromatics are present in nearly equal numbers in the WL sample (320 monocyclic and 297 polycyclic aromatic formulae). The high fraction of aromatics present in the winter samples is consistent with the results from Wang et al. (2018), who also compared filter samples collected in Beijing wintertime air under high- and low-pollution conditions. As mentioned previously, a lot of the polycyclic aromatic compounds are likely oxidised PAHs. Oxidised PAHs such as nitro-PAH, oxy-PAH and hydroxy-PAH can be produced either directly from incomplete combustion or pyrolysis of fossil fuel and biomass or through oxidation of PAHs in the atmosphere (Albinet et al., 2007; Andreou and Rapsomanikis, 2009; Atkinson and Arey, 1994; Bandowe and Meusel, 2017; Walgraeve et al., 2010). Bandowe et al. (2014) found higher concentrations of oxidised PAHs in winter in Xi'an, a Chinese megacity. They partially attribute this increase to heating activities. A similar increase in the concentration of oxidised PAHs during the heating season was observed in Beijing by Lin et al. (2015), who also state that this increase might be linked to winter heating activities. Their source apportionment showed that oxy- and hydroxy-PAHs in particular are dominated by biomass burning emissions during the heating season. They state that during the non-heating period, secondary sources become more relevant due to increased photochemical activity, dominating as a source for oxy-and nitro-PAHs. This is consistent with our observations of increased $\mathrm{O} / \mathrm{C}$ during the summer (Table 1). Studies by Liu et al. (2019) and Lyu et al. (2019) confirm that coal combustion and biomass burning where significant sources of particulate matter during the APHH winter campaign, while a quantitative comparison with the summer is still pending.

To further investigate the different aromatic compounds, the approximate average carbon oxidation state $\left(\overline{\mathrm{OS}}_{\mathrm{C}}\right)$ for each formula was plotted against the number of carbon atoms $\left(n_{\mathrm{C}}\right)$, with all formulae classified as polycyclic aromatics, monocyclic aromatics or non-aromatic. Results for $\mathrm{CHO}$ compounds are shown in Fig. 7, while results for the CHON compounds can be found in the Supplement (Fig. S3). $\overline{\mathrm{OS}}_{\mathrm{C}}$ was calculated for each molecule as follows (Kroll et al., 2011):

$\overline{\mathrm{OS}}_{\mathrm{C}} \approx 2 \mathrm{O} / \mathrm{C}-\mathrm{H} / \mathrm{C}$,

where $\mathrm{O}, \mathrm{C}$ and $\mathrm{H}$ are the number of oxygen, carbon and hydrogen atoms respectively.$\overline{\mathrm{OS}}_{\mathrm{C}}$ is used as an alternative metric to $\mathrm{O} / \mathrm{C}$ for assessing the degree of oxidation since the $\mathrm{O} / \mathrm{C}$ ratio of organic compounds can also change when
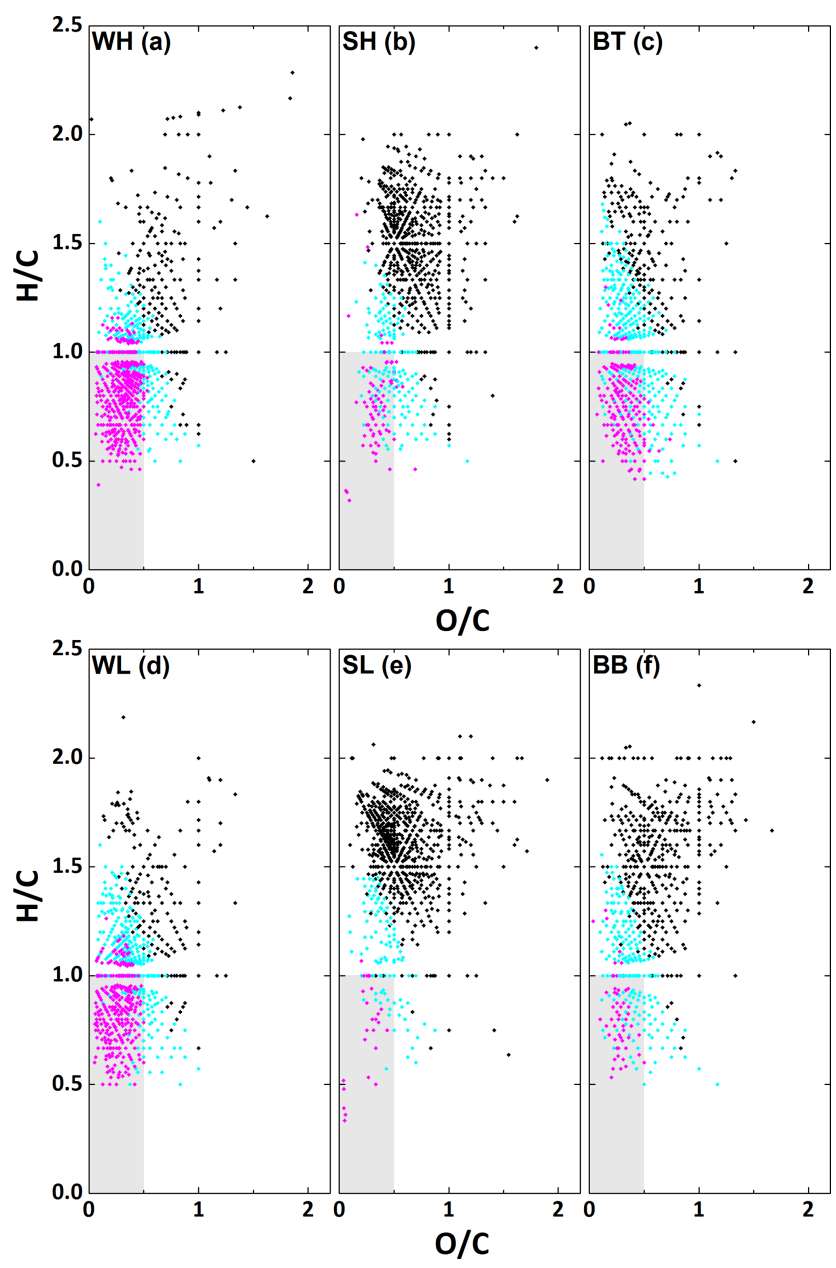

Figure 6. Van Krevelen plot for the WH, WL, SH, SL, BT and BB sample sets. Polycyclic aromatic $(2.7143 \leq \mathrm{Xc})$, monocyclicaromatic $(2.5000 \leq \mathrm{Xc} \leq 2.7143)$ and non-aromatic $(\mathrm{Xc} \leq 2.5000)$ formulae for all $\mathrm{CHO}$ and $\mathrm{CHON}$ ions present in the samples are indicated in magenta, cyan and black, respectively. The aromatic region is shaded in grey.

a compound undergoes non-oxidative reactions. As different formulae can have the same combination of $\overline{\mathrm{OS}}_{\mathrm{C}}$ and carbon number, Figs. 7 and S3 have a lot of overlapping points. In Fig. S4, an offset was applied to the overlapping points to make more data points visible. Figure 7 shows that the summer samples contain large numbers of aliphatic $\mathrm{CHO}$ formulae with a huge range of different carbon numbers, whereas the non-aromatic formulae in the winter samples only rarely have more than 15 carbons. This is possibly due to increased biogenic emissions of long-chain fatty acids, alkenes and similar compounds during summer.

The majority of the polycyclic aromatics and monocyclic aromatics in the summer are below a carbon number of 20 (C20). Similarly, the BT sample, where road traffic is the main source, contains hardly any polycyclic aromatics above C18 and only few monocyclic aromatics above C20. This 

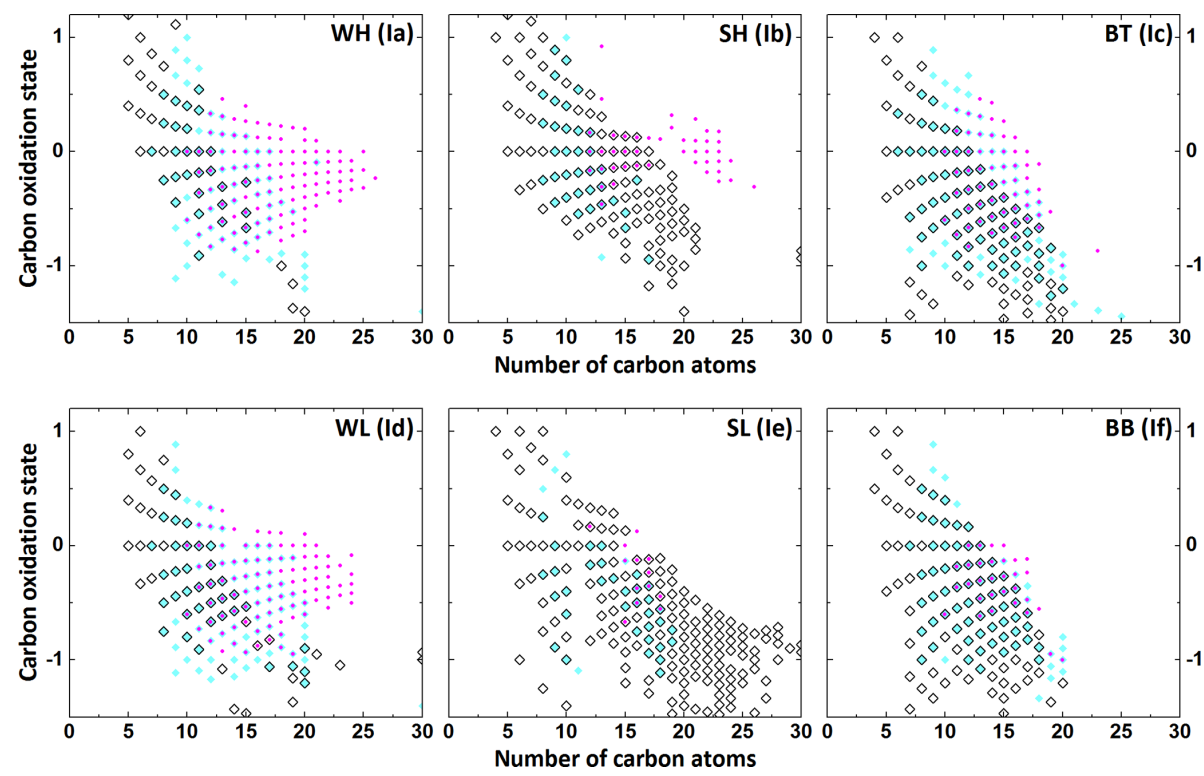

Figure 7. Plot of carbon oxidation state against carbon number for all CHO formulae in the WH, WL SH, SL, BT and BB samples. Polycyclic aromatic $(2.7143 \leq \mathrm{Xc})$, monocyclic aromatic $(2.5000 \leq \mathrm{Xc} \leq 2.7143)$ and non-aromatic $(\mathrm{Xc} \leq 2.5000)$ formulae are depicted as magenta circles, cyan diamonds and open black diamonds respectively.

is in strong contrast with the winter samples from Beijing, which show a strong presence of polycyclic aromatics with up to 25 carbon atoms. The winter samples contain large numbers of aromatics, especially polycyclic aromatics above C15. The likely source for these is heating, as they are present in large numbers in both WH and WL yet not in the summer. This link between higher-ring-number polyaromatics and residential heating is supported by studies showing a sharp increase in the concentration of higher-ring-number PAHs at the start of the heating season in Beijing (Zhang et al., 2017a) and increased emissions of higher-ring-number PAHs for coal combustion compared to gasoline and diesel (Huang et al., 2014). Similar trends can be observed for the CHON compounds in Fig. S3.

\subsection{Sulfur- and nitrogen-containing compounds}

The mass spectra of all four investigated conditions show that the majority of assigned formulae contain sulfur and/or nitrogen atoms. Organic compounds containing sulfur and nitrogen such as organosulfates, organosulfonates, nitrooxyorganosulfates, amines, organonitrates and nitro compounds are prevalent in the atmosphere (Bandowe et al., 2014; Canales et al., 2018; Huang et al., 2012b; Iinuma et al., 2007; Kiendler-Scharr et al., 2016; Kristensen and Glasius, 2011; Lee et al., 2016; Riva et al., 2015; Valle-Hernández et al., 2010). As mentioned previously, all ionisation methods for mass spectrometry differ in their ionisation efficiency towards different compounds. Nonpolar compounds are generally not ionised well in ESI, and the negative-mode ESI is not sensitive towards reduced nitrogen compounds such as amines and imines, while organosulfates, organosulfonates, organonitrates and nitro compounds should ionise well.

Organosulfates are estimated to contribute as much as $30 \%$ to organic fine particle mass (Surratt et al., 2008). Secondary organosulfate formation likely proceeds through particle-phase chemistry via a variety of proposed mechanisms such as esterification of hydroxyl and keto groups (Liggio and $\mathrm{Li}, 2006$ ), acid-catalysed ring-opening of epoxides (Iinuma et al., 2009; Minerath and Elrod, 2009), radicalinitiated processes (Galloway et al., 2009; Nozière et al., 2010) and the direct reaction of $\mathrm{SO}_{2}$ with unsaturated compounds (Passananti et al., 2016). Inorganic $\mathrm{SO}_{4}^{2-}$ in particles is formed through oxidation of sulfur dioxide, which is primarily emitted from anthropogenic sources, especially over land (Smith et al., 2001). In Beijing, $\mathrm{SO}_{2}$ concentrations tend to be particularly high in winter (Zhang et al., 2011; Zhou et al., 2015), with a large contribution from heating (Huang et al., 2012a). However, the resulting concentration of $\mathrm{SO}_{4}^{2-}$ also strongly depends on the rate of $\mathrm{SO}_{2}$ oxidation. In Beijing, average $\mathrm{SO}_{4}^{2-}$ concentrations in fine particles are usually higher in summer than in winter (Chen et al., 2017; Hu et al., 2016; Huang et al., 2016; Liu et al., 2017), which is attributed to increased photooxidation during summer. In our study, the average sulfate concentration was however slightly lower in summer $\left(6.9 \mu \mathrm{g} \mathrm{m}^{-3}\right)$ than in winter $\left(8.5 \mu \mathrm{g} \mathrm{m}^{-3}\right)$. This unusually low concentration compared to the cited studies might be due to the fact that our campaign was conducted earlier in summer than the others. Studies have also shown that the formation rate of $\mathrm{SO}_{4}^{2-}$ is particularly high during haze episodes, with a strong contribution from heterogeneous oxidation within haze droplets (Ma et al., 2018; Wang et al., 
2006), leading to high maximum concentrations of sulfate during haze events, of which several strong ones occurred in winter during our campaign. While organosulfate formation has been primarily understood to be a secondary process, a recent direct-infusion UHRMS study of coal combustion by Song et al. (2019) found 5\%-25\% of formulae in the methanol-extracted fraction to contain sulfur, indicating the potential importance of direct organosulfate emissions. A study by Wang et al. (2019) showed that organosulfates in wintertime $\mathrm{PM}_{2.5}$ in Beijing originated from multiple types of biogenic and anthropogenic precursors.

The majority of S-containing formulae in our samples contain only one sulfur atom. Out of those, most ( $\geq 99 \%$ for $\mathrm{WH}$ and $\mathrm{WL},>92 \%$ for $\mathrm{SH}$ and $\mathrm{SL}$ ) also contain at least four oxygen atoms, marking them as potential organosulfates. This is in line with previous studies (Jiang et al., 2016; Tao et al., 2014; Wang et al., 2019). For the CHONS formulae, $77 \%$ in WH, $94 \%$ in WL, $86 \%$ in SH and $91 \%$ in SL have at least seven oxygen atoms, indicating potential nitrooxy organosulfates.

Unlike organosulfates, formation of organonitrates is thought to occur mostly in the gas phase through for example the reaction of peroxy radicals with $\mathrm{NO}$ or oxidation of volatile organic compounds through the $\mathrm{NO}_{3}$ radical $(\mathrm{Ng}$ et al., 2017; Zhang et al., 2004). Inorganic $\mathrm{NO}_{3}^{-}$in particles is predominantly present in the form of $\mathrm{NH}_{4} \mathrm{NO}_{3}$, which is formed through reaction of $\mathrm{NH}_{3}$ with $\mathrm{HNO}_{3}$. The dominant pathways for $\mathrm{HNO}_{3}$ formation are the reaction of $\mathrm{NO}_{2}$ with $\mathrm{OH}$ radical during daytime and $\mathrm{N}_{2} \mathrm{O}_{5}$ hydrolysis during the night (Bauer et al., 2007; Khoder, 2002). In Beijing, ammonium-poor particles were found to still have very high $\mathrm{NO}_{3}^{-}$content. It has been suggested that hydrolysis of $\mathrm{N}_{2} \mathrm{O}_{5}$ in particles is responsible for this phenomenon (Pathak et al., 2009). Just like for $\mathrm{SO}_{4}^{2-}, \mathrm{NO}_{3}^{-}$concentrations in Beijing are enhanced during haze episodes (Huang et al., 2016; Wang et al., 2006). Apart from organonitrates, nitroaromatics are another important class of N-containing organics in the atmosphere which can be detected in negative-mode ESI. They can either be emitted directly via combustion of biomass and fossil fuels (Heeb et al., 2008; Karavalakis et al., 2010; Wang et al., 2017b) or formed in the atmosphere through reaction of aromatics (Keyte et al., 2013). Apart from being both a primary and secondary source of nitroaromatics, biomass burning can also lead to formation of other nitrogen-containing organics, such as alkaloids (Laskin et al., 2009). However, these compounds are unlikely to be detected in negativemode ESI.

The majority of detected $\mathrm{N}$-containing formulae $(97 \% \mathrm{WH}, 89 \% \mathrm{WL}, 98 \% \mathrm{SH}$ and $97 \% \mathrm{SL})$ also contained at least three oxygen atoms, marking them as potential organonitrates. Nitro compounds on the other hand have a minimum of two oxygens per molecule, which is the case for $>99 \%$ of $\mathrm{N}$-containing formulae in the $\mathrm{WH}, \mathrm{SH}$ and SL samples and $96 \%$ in the WL sample.

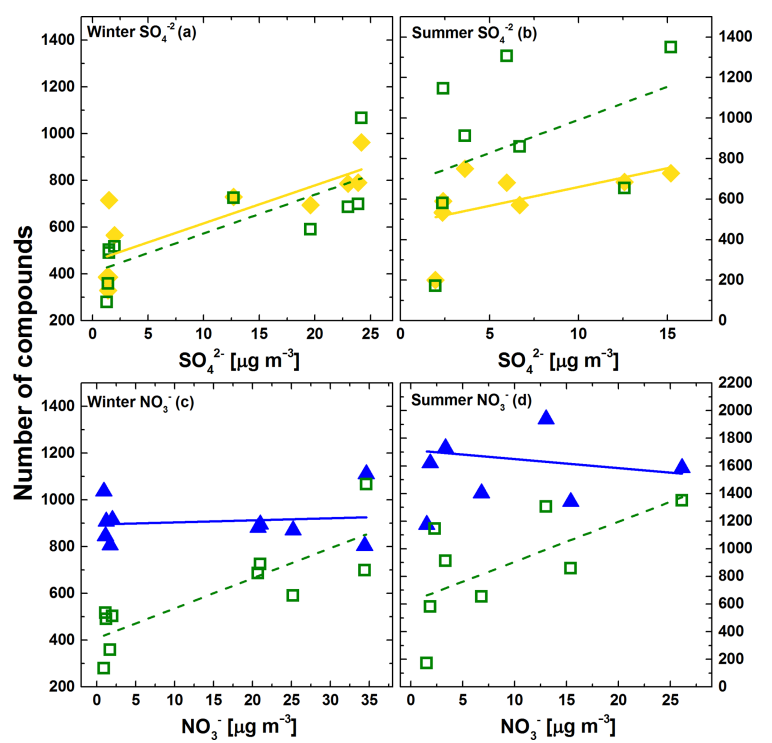

Figure 8. Number of molecular formula with the elemental composition CHOS (yellow diamonds), CHONS (green square) and $\mathrm{CHON}$ (blue triangles) plotted against the concentration of $\mathrm{SO}_{4}^{2-}(\mathbf{a}, \mathbf{b})$ or $\mathrm{NO}_{3}^{-}(\mathbf{c}, \mathbf{d})$ in the particle phase, analysed via ion chromatography. An overview of the correlation parameters can be found in the Supplement (Table S4).

To obtain further information about the potential sources of the sulfur- and nitrogen-containing compounds in our study, the total number of molecular formulae containing sulfur and/or nitrogen were plotted against the concentration of inorganic sulfate $\left(\mathrm{SO}_{4}^{2-}\right)$ and nitrate $\left(\mathrm{NO}_{3}^{-}\right)$(Fig. 8) for each measured sample respectively. The direct-infusion MS analyses done here do not allow us to determine compound concentrations accurately; thus we use the number of CHOS compounds as an indicator for the importance of the formation processes for S-containing organic compounds. An overview of the correlation parameters can be found in the Supplement (Table S4). For the winter samples, there was a statistically significant positive correlation between the number of CHOS formulae and the concentration of inorganic $\mathrm{SO}_{4}^{2-}$ on that day (Fig. 8a), corroborating results of other studies that S-containing organics are formed in the particle phase. The sulfate data did not correlate as well for summer (Fig. 8b), which might be explained by the lower maximum concentrations of $\mathrm{SO}_{4}^{2-}$ and the on average slightly lower $\mathrm{SO}_{4}^{2-}$ concentrations during our summer campaign, where particle-phase formation reactions of S-containing organics might become less important. Very similar trends are observed for CHONS, suggesting common formation routes for these compounds as for CHOS. The ions that are found only in the WH and not the WL sample are likely to be representative of winter haze events. Over half of these components are sulfur containing (Fig. S1) - which suggests high formation rates for organic sulfurous compounds during win- 
ter haze events. Wang et al. (2019) found that organosulfates with a high carbon number were significantly more abundant in polluted Beijing winter samples than in samples taken under low-pollution conditions, which indicates that in polluted air, more organosulfates are generated from long-chain alkanes.

It can be seen in panel $\mathrm{c}$ and $\mathrm{d}$ of Fig. 8 that the number of $\mathrm{CHON}$ formulae does not correlate significantly with the $\mathrm{NO}_{3}^{-}$concentration, while CHONS does, though this correlation is only statistically significant for the winter samples. This suggests that in contrast to the S-containing organics, most $\mathrm{N}$-containing organics detected in our samples are not formed in the particle phase. As stated earlier, the detection mode we used is biased towards oxidised N-containing organics such as organic nitrates, which are known to form predominantly in the gas phase and nitro compounds, which can be of either primary or secondary origin, with a strong contribution of gas-phase oxidation in the second case. A correlation with particle-phase nitrate is therefore not expected.

\section{Conclusions}

$\mathrm{PM}_{2.5}$ filter samples from Beijing from the winter and summer APHH-Beijing campaign were analysed with direct injection ultrahigh-resolution mass spectrometry. A strong variation in the composition of organic particles was observed between high- and low-pollution conditions as well as between the two seasons. In summer significantly more CHON formulae were detected compared to winter, likely due to the increased $\mathrm{NO}_{x}$-driven photochemistry in summer. S-containing formulae were more dominant during highpollution events in both seasons and highest during winter haze events. The contribution of aromatic compounds was strongly increased in winter, likely due to heating as an additional source. The relative contribution of S-containing formulae increased under high-pollution conditions, and the number of S-containing formulae showed correlation with inorganic $\mathrm{SO}_{4}^{2-}$ on the filters, consistent with a particle-phase formation process, while no such correlation was found for $\mathrm{N}$-containing formulae and inorganic $\mathrm{NO}_{3}^{-}$.

Data availability. The direct-infusion ultrahigh-resolution mass spectrometry data are available through the CEDA Archive (https:// catalogue.ceda.ac.uk/uuid/680ebdcb83c244fdb9d069e2f8952812), last access: 20 July 2020, Steimer and Kalberer, 2020.

Supplement. The supplement related to this article is available online at: https://doi.org/10.5194/acp-20-13303-2020-supplement.
Author contributions. MK and SSS designed the research. DJP and SSS performed the mass spectrometry measurements and data analysis. TVV measured the ion chromatography data. MP ran the NAME model. SSS wrote the manuscript with contributions from all co-authors.

Competing interests. The authors declare that they have no conflict of interest.

Special issue statement. This article is part of the special issue "In-depth study of air pollution sources and processes within Beijing and its surrounding region (APHH-Beijing) (ACP/AMT interjournal SI)". It is not associated with a conference.

Acknowledgements. We acknowledge the support from Pingqing $\mathrm{Fu}$, Zifa Wang, Jie $\mathrm{Li}$ and Yele Sun from IAP for hosting the APHH-Beijing campaign at IAP. We thank Di Liu and Bill Bloss from the University of Birmingham; Siyao Yue, Liangfang Wei, Hong Ren, Qiaorong Xie, Wanyu Zhao, Linjie Li, Ping Li, Shengjie Hou and Qingqing Wang from IAP; Rachel Dunmore, Ally Lewis and James Lee from the University of York; Kebin He and Xiaoting Cheng from Tsinghua University; and James Allan and Hugh Coe from the University of Manchester for providing logistic and scientific support for the field campaigns.

Financial support. This research has been supported by the Natural Environment Research Council (grant nos. NE/N007190/1 and NE/N007158/1) as part of the APHH-Beijing study, the Swiss National Science Foundation (project no. P2EZP2_162258) and the AXA Research Fund (through a 2017-LIFE-PostDoc fellowship).

Review statement. This paper was edited by Mei Zheng and reviewed by three anonymous referees.

\section{References}

Albinet, A., Leoz-Garziandia, E., Budzinski, H., and Villenave, E.: Polycyclic aromatic hydrocarbons (PAHs), nitrated PAHs and oxygenated PAHs in ambient air of the Marseilles area (South of France): Concentrations and sources, Sci. Total Environ., 384, 280-292, https://doi.org/10.1016/j.scitotenv.2007.04.028, 2007.

Andreou, G. and Rapsomanikis, S.: Polycyclic aromatic hydrocarbons and their oxygenated derivatives in the urban atmosphere of Athens, J. Hazard. Mater., 172, 363-373, https://doi.org/10.1016/j.jhazmat.2009.07.023, 2009.

Atkinson, R. and Arey, J.: Atmospheric chemistry of gasphase polycyclic aromatic hydrocarbons: formation of atmospheric mutagens, Environ. Health Persp., 102, 117-126, https://doi.org/10.1289/ehp.94102s4117, 1994.

Baek, S. O., Field, R. A., Goldstone, M. E., Kirk, P. W., Lester, J. N., and Perry, R.: A review of atmospheric polycyclic aromatic hy- 
drocarbons: Sources, fate and behavior, Water. Air. Soil Pollut., 60, 279-300, https://doi.org/10.1007/BF00282628, 1991.

Bandowe, B. A. M. and Meusel, H.: Nitrated polycyclic aromatic hydrocarbons (nitro-PAHs) in the environment - A review, Sci. Total Environ., 581-582, 237-257, https://doi.org/10.1016/j.scitotenv.2016.12.115, 2017.

Bandowe, B. A. M., Meusel, H., Huang, R., Ho, K., Cao, J., Hoffmann, T., and Wilcke, W.: $\mathrm{PM}_{2.5}$-bound oxygenated PAHs, nitro-PAHs and parent-PAHs from the atmosphere of a Chinese megacity: Seasonal variation, sources and cancer risk assessment, Sci. Total Environ., 473-474, 77-87, https://doi.org/10.1016/j.scitotenv.2013.11.108, 2014.

Bauer, S. E., Koch, D., Unger, N., Metzger, S. M., Shindell, D. T., and Streets, D. G.: Nitrate aerosols today and in 2030: a global simulation including aerosols and tropospheric ozone, Atmos. Chem. Phys., 7, 5043-5059, https://doi.org/10.5194/acp-7-50432007, 2007.

Brown, A., Milton, S., Cullen, M., Golding, B., Mitchell, J., and Shelly, A.: Unified Modeling and Prediction of Weather and Climate: A 25-Year Journey, B. Am. Meteorol. Soc., 93, 1865-1877, https://doi.org/10.1175/BAMS-D-12-00018.1, 2012.

Canales, R., Achad, M., Smichowski, P., Gómez, D., Reta, M., and Cerutti, S.: Determination of heterocyclic aromatic amines in airborne particulate matter $\left(\mathrm{PM}_{2.5}\right.$ and $\left.\mathrm{PM}_{10}\right)$ from different emission sources by ultra-high performance liquid chromatography-tandem mass spectrometry, Microchem. J., 139, 34-41, https://doi.org/10.1016/j.microc.2018.02.012, 2018.

Chan, C. K. and Yao, X.: Air pollution in mega cities in China, Atmos. Environ., 42, 1-42, https://doi.org/10.1016/j.atmosenv.2007.09.003, 2008.

Chen, R., Cheng, J., Lv, J., Wu, L., and Wu, J.: Comparison of chemical compositions in air particulate matter during summer and winter in Beijing, China, Environ. Geochem. Health, 39, 913-921, https://doi.org/10.1007/s10653-016-9862-9, 2017.

Cohen, A. J., Brauer, M., Burnett, R., et al.: Estimates and 25year trends of the global burden of disease attributable to ambient air pollution: an analysis of data from the Global Burden of Diseases Study 2015, Lancet, 389, 1907-1918, https://doi.org/10.1016/S0140-6736(17)30505-6, 2017.

Dockery, D. W., Pope, C. A., Xu, X., Spengler, J. D., Ware, J. H., Fay, M. E., Ferris, B. G., and Speizer, F. E.: An Association between Air Pollution and Mortality in Six U.S. Cities, N. Engl. J. Med., 329, 1753-1759, https://doi.org/10.1056/NEJM199312093292401, 1993.

Dzepina, K., Mazzoleni, C., Fialho, P., China, S., Zhang, B., Owen, R. C., Helmig, D., Hueber, J., Kumar, S., Perlinger, J. A., Kramer, L. J., Dziobak, M. P., Ampadu, M. T., Olsen, S., Wuebbles, D. J., and Mazzoleni, L. R.: Molecular characterization of free tropospheric aerosol collected at the Pico Mountain Observatory: a case study with a long-range transported biomass burning plume, Atmos. Chem. Phys., 15, 5047-5068, https://doi.org/10.5194/acp-15-5047-2015, 2015.

Elzein, A., Dunmore, R. E., Ward, M. W., Hamilton, J. F., and Lewis, A. C.: Variability of polycyclic aromatic hydrocarbons and their oxidative derivatives in wintertime Beijing, China, Atmos. Chem. Phys., 19, 8741-8758, https://doi.org/10.5194/acp19-8741-2019, 2019.

Feng, J., Chan, C. K., Fang, M., Hu, M., He, L., and Tang, X.: Impact of meteorology and energy struc- ture on solvent extractable organic compounds of $\mathrm{PM}_{2.5}$ in Beijing, China, Chemosphere, 61, 623-632, https://doi.org/10.1016/j.chemosphere.2005.03.067, 2005.

Galloway, M. M., Chhabra, P. S., Chan, A. W. H., Surratt, J. D., Flagan, R. C., Seinfeld, J. H., and Keutsch, F. N.: Glyoxal uptake on ammonium sulphate seed aerosol: reaction products and reversibility of uptake under dark and irradiated conditions, Atmos. Chem. Phys., 9, 3331-3345, https://doi.org/10.5194/acp-93331-2009, 2009.

Gao, J., Wang, K., Wang, Y., Liu, S., Zhu, C., Hao, J., Liu, H., Hua, S., and Tian, H.: Temporal-spatial characteristics and source apportionment of $\mathrm{PM}_{2.5}$ as well as its associated chemical species in the Beijing-TianjinHebei region of China, Environ. Pollut., 233, 714-724, https://doi.org/10.1016/j.envpol.2017.10.123, 2018.

Gelencsér, A., May, B., Simpson, D., Sánchez-Ochoa, A., KasperGiebl, A., Puxbaum, H., Caseiro, A., Pio, C., and Legrand, M.: Source apportionment of $\mathrm{PM}_{2.5}$ organic aerosol over Europe: Primary/secondary, natural/anthropogenic, and fossil/biogenic origin, J. Geophys. Res.-Atmos., 112, D23S04, https://doi.org/10.1029/2006JD008094, 2007.

Gentner, D. R., Isaacman, G., Worton, D. R., Chan, A. W. H., Dallmann, T. R., Davis, L., Liu, S., Day, D. A., Russell, L. M., Wilson, K. R., Weber, R., Guha, A., Harley, R. A., and Goldstein, A. H.: Elucidating secondary organic aerosol from diesel and gasoline vehicles through detailed characterization of organic carbon emissions, P. Natl. Acad. Sci. USA, 109, 18318-18323, https://doi.org/10.1073/pnas.1212272109, 2012.

Gentner, D. R., Jathar, S. H., Gordon, T. D., Bahreini, R., Day, D. A., El Haddad, I., Hayes, P. L., Pieber, S. M., Platt, S. M., de Gouw, J., Goldstein, A. H., Harley, R. A., Jimenez, J. L., Prévôt, A. S. H., and Robinson, A. L.: Review of Urban Secondary Organic Aerosol Formation from Gasoline and Diesel Motor Vehicle Emissions, Environ. Sci. Technol., 51, 1074 1093, https://doi.org/10.1021/acs.est.6b04509, 2017.

Giorio, C., Bortolini, C., Kourtchev, I., Tapparo, A., Bogialli, S., and Kalberer, M.: Direct target and non-target analysis of urban aerosol sample extracts using atmospheric pressure photoionisation high-resolution mass spectrometry, Chemosphere, 224, 786795, https://doi.org/10.1016/j.chemosphere.2019.02.151, 2019.

Goldstein, A. H. and Galbally, I. E.: Known and Unexplored Organic Constituents in the Earth's Atmosphere, Environ. Sci. Technol., 41, 1514-1521, https://doi.org/10.1021/es072476p, 2007.

Guan, W.-J., Zheng, X.-Y., Chung, K. F., and Zhong, N.-S.: Impact of air pollution on the burden of chronic respiratory diseases in China: time for urgent action, Lancet, 388, 1939-1951, https://doi.org/10.1016/S0140-6736(16)31597-5, 2016.

Hamilton, J. F. and Lewis, A. C.: Monoaromatic complexity in urban air and gasoline assessed using comprehensive GC and fast GC-TOF/MS, Atmos. Environ., 37, 589-602, https://doi.org/10.1016/S1352-2310(02)00930-5, 2003.

He, K., Yang, F., Ma, Y., Zhang, Q., Yao, X., Chan, C. K., Cadle, S., Chan, T., and Mulawa, P.: The characteristics of $\mathrm{PM}_{2.5}$ in Beijing, China, Atmos. Environ., 35, 4959-4970, https://doi.org/10.1016/S1352-2310(01)00301-6, 2001.

Heeb, N. V, Schmid, P., Kohler, M., Gujer, E., Zennegg, M., Wenger, D., Wichser, A., Ulrich, A., Gfeller, U., Honegger, P., Zeyer, K., Emmenegger, L., Petermann, J.-L., Czerwinski, J., 
Mosimann, T., Kasper, M., and Mayer, A.: Secondary Effects of Catalytic Diesel Particulate Filters: Conversion of PAHs versus Formation of Nitro-PAHs, Environ. Sci. Technol., 42, 37733779, https://doi.org/10.1021/es7026949, 2008.

Hoek, G., Krishnan, R. M., Beelen, R., Peters, A., Ostro, B., Brunekreef, B., and Kaufman, J. D.: Long-term air pollution exposure and cardio- respiratory mortality: a review, Environ. Heal., 12, 43, https://doi.org/10.1186/1476-069X-12-43, 2013.

Hu, J., Wang, Y., Ying, Q., and Zhang, H.: Spatial and temporal variability of $\mathrm{PM}_{2.5}$ and $\mathrm{PM}_{10}$ over the North China Plain and the Yangtze River Delta, China, Atmos. Environ., 95, 598-609, https://doi.org/10.1016/j.atmosenv.2014.07.019, 2014.

Hu, J., Wang, P., Ying, Q., Zhang, H., Chen, J., Ge, X., Li, X., Jiang, J., Wang, S., Zhang, J., Zhao, Y., and Zhang, Y.: Modeling biogenic and anthropogenic secondary organic aerosol in China, Atmos. Chem. Phys., 17, 77-92, https://doi.org/10.5194/acp-1777-2017, 2017.

Hu, W., Hu, M., Hu, W., Jimenez, J. L., Yuan, B., Chen, W., Wang, M., Wu, Y., Chen, C., Wang, Z., Peng, J., Zeng, L., and Shao, M.: Chemical composition, sources, and aging process of submicron aerosols in Beijing: Contrast between summer and winter, J. Geophys. Res.-Atmos., 121, 1955-1977, https://doi.org/10.1002/2015JD024020, 2016.

Huang, C., Wang, H. L., Li, L., Wang, Q., Lu, Q., de Gouw, J. A., Zhou, M., Jing, S. A., Lu, J., and Chen, C. H.: VOC species and emission inventory from vehicles and their SOA formation potentials estimation in Shanghai, China, Atmos. Chem. Phys., 15, 11081-11096, https://doi.org/10.5194/acp-15-110812015, 2015.

Huang, Q., Cheng, S., Perozzi, R. E., and Perozzi, E. F.: Use of a MM5-CAMx-PSAT Modeling System to Study $\mathrm{SO}_{2}$ Source Apportionment in the Beijing Metropolitan Region, Environ. Model. Assess., 17, 527-538, https://doi.org/10.1007/s10666012-9312-8, 2012a.

Huang, W., Huang, B., Bi, X., Lin, Q., Liu, M., Ren, Z., Zhang, G., Wang, X., Sheng, G., and Fu, J.: Emission of PAHs, NPAHs and OPAHs from residential honeycomb coal briquette combustion, Energ. Fuel., 2, 636-642, https://doi.org/10.1021/ef401901d, 2014.

Huang, X., Liu, Z., Zhang, J., Wen, T., Ji, D., and Wang, Y.: Seasonal variation and secondary formation of sizesegregated aerosol water-soluble inorganic ions during pollution episodes in Beijing, Atmos. Res., 168, 70-79, https://doi.org/10.1016/j.atmosres.2015.08.021, 2016.

Huang, Y., Chen, H., Wang, L., Yang, X., and Chen, J.: Single particle analysis of amines in ambient aerosol in Shanghai, Environ. Chem., 9, 202-210, https://doi.org/10.1071/EN11145, 2012b.

Iinuma, Y., Müller, C., Berndt, T., Böge, O., Claeys, M., and Herrmann, H.: Evidence for the Existence of Organosulfates from $\beta$-Pinene Ozonolysis in Ambient Secondary Organic Aerosol, Environ. Sci. Technol., 41, 6678-6683, https://doi.org/10.1021/es070938t, 2007.

Iinuma, Y., Böge, O., Kahnt, A., and Herrmann, H.: Laboratory chamber studies on the formation of organosulfates from reactive uptake of monoterpene oxides, Phys. Chem. Chem. Phys., 11, 7985-7997, https://doi.org/10.1039/B904025K, 2009.

Jiang, B., Kuang, B. Y., Liang, Y., Zhang, J., Huang, X. H. H., $\mathrm{Xu}, \mathrm{C}$., Yu, J. Z., and Shi, Q.: Molecular composition of urban organic aerosols on clear and hazy days in Beijing: a com- parative study using FT-ICR MS, Environ. Chem., 13, 888-901, https://doi.org/10.1071/EN15230, 2016.

Jimenez, J. L., Canagaratna, M. R., Donahue, N. M., Prevot, A. S. H., Zhang, Q., Kroll, J. H., DeCarlo, P. F., Allan, J. D., Coe, H., Ng, N. L., Aiken, A. C., Docherty, K. S., Ulbrich, I. M., Grieshop, A. P., Robinson, A. L., Duplissy, J., Smith, J. D., Wilson, K. R., Lanz, V. A., Hueglin, C., Sun, Y. L., Tian, J., Laaksonen, A., Raatikainen, T., Rautiainen, J., Vaattovaara, P., Ehn, M., Kulmala, M., Tomlinson, J. M., Collins, D. R., Cubison, M. J., Dunlea, J., Huffman, J. A., Onasch, T. B., Alfarra, M. R., Williams, P. I., Bower, K., Kondo, Y., Schneider, J., Drewnick, F., Borrmann, S., Weimer, S., Demerjian, K., Salcedo, D., Cottrell, L., Griffin, R., Takami, A., Miyoshi, T., Hatakeyama, S., Shimono, A., Sun, J. Y., Zhang, Y. M., Dzepina, K., Kimmel, J. R., Sueper, D., Jayne, J. T., Herndon, S. C., Trimborn, A. M., Williams, L. R., Wood, E. C., Middlebrook, A. M., Kolb, C. E., Baltensperger, U., and Worsnop, D. R.: Evolution of Organic Aerosols in the Atmosphere, Science, 326, 1525-1529, https://doi.org/10.1126/science.1180353, 2009.

Jones, A., Thomson, D., Hort, M., and Devenish, B.: The U.K. Met Office's Next-Generation Atmospheric Dispersion Model, NAME III, in: Air Pollution Modeling and Its Application XVII, edited by: Borrego, C. and Norman, A.-L., 580-589, Springer US, Boston, MA, 2007.

Kanakidou, M., Seinfeld, J. H., Pandis, S. N., Barnes, I., Dentener, F. J., Facchini, M. C., Van Dingenen, R., Ervens, B., Nenes, A., Nielsen, C. J., Swietlicki, E., Putaud, J. P., Balkanski, Y., Fuzzi, S., Horth, J., Moortgat, G. K., Winterhalter, R., Myhre, C. E. L., Tsigaridis, K., Vignati, E., Stephanou, E. G., and Wilson, J.: Organic aerosol and global climate modelling: a review, Atmos. Chem. Phys., 5, 1053-1123, https://doi.org/10.5194/acp-5-10532005, 2005.

Karavalakis, G., Deves, G., Fontaras, G., Stournas, S., Samaras, Z., and Bakeas, E.: The impact of soy-based biodiesel on PAH, nitro$\mathrm{PAH}$ and oxy-PAH emissions from a passenger car operated over regulated and nonregulated driving cycles, Fuel, 89, 3876-3883, https://doi.org/10.1016/j.fuel.2010.07.002, 2010.

Keyte, I. J., Harrison, R. M., and Lammel, G.: Chemical reactivity and long-range transport potential of polycyclic aromatic hydrocarbons - a review, Chem. Soc. Rev., 42, 9333-9391, https://doi.org/10.1039/C3CS60147A, 2013.

Khoder, M. I.: Atmospheric conversion of sulfur dioxide to particulate sulfate and nitrogen dioxide to particulate nitrate and gaseous nitric acid in an urban area, Chemosphere, 49, 675-684, https://doi.org/10.1016/S0045-6535(02)00391-0, 2002.

Kiendler-Scharr, A., Mensah, A. A., Friese, E., Topping, D., Nemitz, E., Prevot, A. S. H., Äijälä, M., Allan, J., Canonaco, F., Canagaratna, M., Carbone, S., Crippa, M., Dall Osto, M., Day, D. A., De Carlo, P., Di Marco, C. F., Elbern, H., Eriksson, A., Freney, E., Hao, L., Herrmann, H., Hildebrandt, L., Hillamo, R., Jimenez, J. L., Laaksonen, A., McFiggans, G., Mohr, C., O’Dowd, C., Otjes, R., Ovadnevaite, J., Pandis, S. N., Poulain, L., Schlag, P., Sellegri, K., Swietlicki, E., Tiitta, P., Vermeulen, A., Wahner, A., Worsnop, D., and Wu, H.-C.: Ubiquity of organic nitrates from nighttime chemistry in the European submicron aerosol, Geophys. Res. Lett., 43, 7735-7744, https://doi.org/10.1002/2016GL069239, 2016.

Kim, S., Kramer, R. W., and Hatcher, P. G.: Graphical Method for Analysis of Ultrahigh-Resolution Broadband Mass Spectra 
of Natural Organic Matter, the Van Krevelen Diagram, Anal. Chem., 75, 5336-5344, https://doi.org/10.1021/ac034415p, 2003.

Kleindienst, T. E., Jaoui, M., Lewandowski, M., Offenberg, J. H., Lewis, C. W., Bhave, P. V., and Edney, E. O.: Estimates of the contributions of biogenic and anthropogenic hydrocarbons to secondary organic aerosol at a southeastern US location, Atmos. Environ., 41, 8288-8300, https://doi.org/10.1016/j.atmosenv.2007.06.045, 2007.

Koch, B. P. and Dittmar, T.: From mass to structure: An aromaticity index for high-resolution mass data of natural organic matter, Rapid Commun. Mass Sp., 20, 926-932, https://doi.org/10.1002/rcm.2386, 2006.

Kourtchev, I., Fuller, S., Aalto, J., Ruuskanen, T. M., McLeod, M. W., Maenhaut, W., Jones, R., Kulmala, M., and Kalberer, M.: Molecular Composition of Boreal Forest Aerosol from Hyytiälä, Finland, Using Ultrahigh Resolution Mass Spectrometry, Environ. Sci. Technol., 47, 4069-4079, https://doi.org/10.1021/es3051636, 2013.

Kristensen, K. and Glasius, M.: Organosulfates and oxidation products from biogenic hydrocarbons in fine aerosols from a forest in North West Europe during spring, Atmos. Environ., 45, 45464556, https://doi.org/10.1016/j.atmosenv.2011.05.063, 2011.

Kroll, J. H., Donahue, N. M., Jimenez, J. L., Kessler, S. H., Canagaratna, M. R., Wilson, K. R., Altieri, K. E., Mazzoleni, L. R., Wozniak, A. S., Bluhm, H., Mysak, E. R., Smith, J. D., Kolb, C. E., and Worsnop, D. R.: Carbon oxidation state as a metric for describing the chemistry of atmospheric organic aerosol Jesse, Nat. Chem., 3, 133-139, https://doi.org/10.1038/nchem.948, 2011.

Lang, J., Zhang, Y., Zhou, Y., Cheng, S., Chen, D., Guo, X., Chen, S., Li, X., Xing, X., and Wang, H.: Trends of $\mathrm{PM}_{2.5}$ and Chemical Composition in Beijing, 2000-2015, Aerosol Air Qual. Res., 17, 412-425, https://doi.org/10.4209/aaqr.2016.07.0307, 2017.

Laskin, A., Smith, J. S., and Laskin, J.: Molecular Characterization of Nitrogen-Containing Organic Compounds in Biomass Burning Aerosols Using High-Resolution Mass Spectrometry, Environ. Sci. Technol., 43, 3764-3771, https://doi.org/10.1021/es803456n, 2009.

Lee, B. H., Mohr, C., Lopez-Hilfiker, F. D., Lutz, A., Hallquist, M., Lee, L., Romer, P., Cohen, R. C., Iyer, S., Kurtén, T., Hu, W., Day, D. A., Campuzano-Jost, P., Jimenez, J. L., Xu, L., Ng, N. L., Guo, H., Weber, R. J., Wild, R. J., Brown, S. S., Koss, A., de Gouw, J., Olson, K., Goldstein, A. H., Seco, R., Kim, S., McAvey, K., Shepson, P. B., Starn, T., Baumann, K., Edgerton, E. S., Liu, J., Shilling, J. E., Miller, D. O., Brune, W., Schobesberger, S., D'Ambro, E. L., and Thornton, J. A.: Highly functionalized organic nitrates in the southeast United States: Contribution to secondary organic aerosol and reactive nitrogen budgets, P. Natl. Acad. Sci. USA, 113, 1516-1521, https://doi.org/10.1073/pnas.1508108113, 2016.

Lelieveld, J., Evans, J. S., Fnais, M., Giannadaki, D., and Pozzer, A.: The contribution of outdoor air pollution sources to premature mortality on a global scale, Nature, 525, 367-371, https://doi.org/10.1038/nature15371, 2015.

Liggio, J. and Li, S.-M.: Organosulfate formation during the uptake of pinonaldehyde on acidic sulfate aerosols, Geophys. Res. Lett., 33, L13808, https://doi.org/10.1029/2006GL026079, 2006.

Lin, P., Hu, M., Deng, Z., Slanina, J., Han, S., Kondo, Y., Takegawa, N., Miyazaki, Y., Zhao, Y., and Sugimoto, N.: Seasonal and diur- nal variations of organic carbon in $\mathrm{PM}_{2.5}$ in Beijing and the estimation of secondary organic carbon, J. Geophys. Res.-Atmos., 114, D00G11, https://doi.org/10.1029/2008JD010902, 2009.

Lin, P., Yu, J. Z., Engling, G., and Kalberer, M.: Organosulfates in Humic-like Substance Fraction Isolated from Aerosols at Seven Locations in East Asia: A Study by Ultra-High-Resolution Mass Spectrometry, Environ. Sci. Technol., 46, 13118-13127, https://doi.org/10.1021/es303570v, 2012.

Lin, Y., Ma, Y., Qiu, X., Li, R., Fang, Y., Wang, J., Zhu, Y., and Hu, D.: Sources, transformation, and health implications of PAHs and their nitrated, hydroxylated, and oxygenated derivatives in $\mathrm{PM}_{2.5}$ in Beijing, J. Geophys. Res.-Atmos., 120, 7219-7228, https://doi.org/10.1002/2015JD023628, 2015.

Liu, Y., Zheng, M., Yu, M., Cai, X., Du, H., Li, J., Zhou, T., Yan, C., Wang, X., Shi, Z., Harrison, R. M., Zhang, Q., and He, K.: High-time-resolution source apportionment of $\mathrm{PM}_{2.5}$ in Beijing with multiple models, Atmos. Chem. Phys., 19, 6595-6609, https://doi.org/10.5194/acp-19-6595-2019, 2019.

Liu, Z., Xie, Y., Hu, B., Wen, T., Xin, J., Li, X., and Wang, Y.: Size-resolved aerosol water-soluble ions during the summer and winter seasons in Beijing: Formation mechanisms of secondary inorganic aerosols, Chemosphere, 183, 119-131, https://doi.org/10.1016/j.chemosphere.2017.05.095, 2017.

Lv, B., Zhang, B., and Bai, Y.: A systematic analysis of $\mathrm{PM}_{2.5}$ in Beijing and its sources from 2000 to 2012, Atmos. Environ., 124, 98-108, https://doi.org/10.1016/j.atmosenv.2015.09.031, 2016.

Lyu, R., Shi, Z., Alam, M. S., Wu, X., Liu, D., Vu, T. V., Stark, C., Fu, P., Feng, Y., and Harrison, R. M.: Insight into the composition of organic compounds $\left(\geq \mathrm{C}_{6}\right)$ in $\mathrm{PM}_{2.5}$ in wintertime in Beijing, China, Atmos. Chem. Phys., 19, 10865-10881, https://doi.org/10.5194/acp-19-10865-2019, 2019.

Ma, J., Chu, B., Liu, J., Liu, Y., Zhang, H., and He, H.: $\mathrm{NO}_{x}$ promotion of $\mathrm{SO}_{2}$ conversion to sulfate: An important mechanism for the occurrence of heavy haze during winter in Beijing, Environ. Pollut., 233, 662-669, https://doi.org/10.1016/j.envpol.2017.10.103, 2018.

May, A. A., Nguyen, N. T., Presto, A. A., Gordon, T. D., Lipsky, E. M., Karve, M., Gutierrez, A., Robertson, W. H., Zhang, M., Brandow, C., Chang, O., Chen, S., Cicero-Fernandez, P., Dinkins, L., Fuentes, M., Huang, S.-M., Ling, R., Long, J., Maddox, C., Massetti, J., McCauley, E., Miguel, A., Na, K., Ong, R., Pang, Y., Rieger, P., Sax, T., Truong, T., Vo, T., Chattopadhyay, S., Maldonado, H., Maricq, M. M., and Robinson, A. L.: Gas- and particle-phase primary emissions from in-use, onroad gasoline and diesel vehicles, Atmos. Environ., 88, 247-260, https://doi.org/10.1016/j.atmosenv.2014.01.046, 2014.

Mazzoleni, L. R., Saranjampour, P., Dalbec, M. M., Samburova, V., Hallar, A. G., Zielinska, B., Lowenthal, D. H., and Kohl, S.: Identification of water-soluble organic carbon in non-urban aerosols using ultrahigh-resolution FT-ICR mass spectrometry: organic anions, Environ. Chem., 9, 285-297, 2012.

McLafferty, F. W. and Tureček, F.: Interpretation of mass spectra, 4th Edn., University Science Books, Sausalito, CA, 1993.

Minerath, E. C. and Elrod, M. J.: Assessing the Potential for Diol and Hydroxy Sulfate Ester Formation from the Reaction of Epoxides in Tropospheric Aerosols, Environ. Sci. Technol., 43, 13861392, https://doi.org/10.1021/es8029076, 2009.

Ng, N. L., Brown, S. S., Archibald, A. T., Atlas, E., Cohen, R. C., Crowley, J. N., Day, D. A., Donahue, N. M., Fry, J. L., 
Fuchs, H., Griffin, R. J., Guzman, M. I., Herrmann, H., Hodzic, A., Iinuma, Y., Jimenez, J. L., Kiendler-Scharr, A., Lee, B. H., Luecken, D. J., Mao, J., McLaren, R., Mutzel, A., Osthoff, H. D., Ouyang, B., Picquet-Varrault, B., Platt, U., Pye, H. O. T., Rudich, Y., Schwantes, R. H., Shiraiwa, M., Stutz, J., Thornton, J. A., Tilgner, A., Williams, B. J., and Zaveri, R. A.: Nitrate radicals and biogenic volatile organic compounds: oxidation, mechanisms, and organic aerosol, Atmos. Chem. Phys., 17, 2103-2162, https://doi.org/10.5194/acp-17-2103-2017, 2017.

Nizkorodov, S. A., Laskin, J., and Laskin, A.: Molecular chemistry of organic aerosols through the application of high resolution mass spectrometry, Phys. Chem. Chem. Phys., 13, 3612-3629, https://doi.org/10.1039/c0cp02032j, 2011.

Nozière, B., Ekström, S., Alsberg, T., and Holmström, S.: Radical-initiated formation of organosulfates and surfactants in atmospheric aerosols, Geophys. Res. Lett., 37, L05806, https://doi.org/10.1029/2009GL041683, 2010.

Nozière, B., Kalberer, M., Claeys, M., Allan, J., D’Anna, B., Decesari, S., Finessi, E., Glasius, M., Grgić, I., Hamilton, J. F., Hoffmann, T., Iinuma, Y., Jaoui, M., Kahnt, A., Kampf, C. J., Kourtchev, I., Maenhaut, W., Marsden, N., Saarikoski, S., Schnelle-Kreis, J., Surratt, J. D., Szidat, S., Szmigielski, R., and Wisthaler, A.: The Molecular Identification of Organic Compounds in the Atmosphere: State of the Art and Challenges, Chem. Rev., 115, 3919-3983, https://doi.org/10.1021/cr5003485, 2015.

Panagi, M., Fleming, Z. L., Monks, P. S., Ashfold, M. J., Wild, O., Hollaway, M., Zhang, Q., Squires, F. A., and Vande Hey, J. D.: Investigating the regional contributions to air pollution in Beijing: a dispersion modelling study using $\mathrm{CO}$ as a tracer, Atmos. Chem. Phys., 20, 2825-2838, https://doi.org/10.5194/acp20-2825-2020, 2020.

Passananti, M., Kong, L., Shang, J., Dupart, Y., Perrier, S., Chen, J., Donaldson, D. J., and George, C.: Organosulfate Formation through the Heterogeneous Reaction of Sulfur Dioxide with Unsaturated Fatty Acids and LongChain Alkenes, Angew. Chem. Int. Edit., 55, 10336-10339, https://doi.org/10.1002/anie.201605266, 2016.

Pathak, R. K., Wu, W. S., and Wang, T.: Summertime $\mathrm{PM}_{2.5}$ ionic species in four major cities of China: nitrate formation in an ammonia-deficient atmosphere, Atmos. Chem. Phys., 9, 17111722, https://doi.org/10.5194/acp-9-1711-2009, 2009.

Pope III, C. A., Burnett, R. T., Thun, M. J., Calle, E. E., Krewski, D., Ito, K., and Thurston, G. D.: Lung Cancer, Cardiopulmonary Mortality, and Long-term Exposure to Fine Particulate Air Pollution, JAMA, 287, 1132-1141, https://doi.org/10.1001/jama.287.9.1132, 2002.

Riva, M., Tomaz, S., Cui, T., Lin, Y.-H., Perraudin, E., Gold, A., Stone, E. A., Villenave, E., and Surratt, J. D.: Evidence for an Unrecognized Secondary Anthropogenic Source of Organosulfates and Sulfonates: Gas-Phase Oxidation of Polycyclic Aromatic Hydrocarbons in the Presence of Sulfate Aerosol, Environ. Sci. Technol., 49, 6654-6664, https://doi.org/10.1021/acs.est.5b00836, 2015.

Schmitt-Kopplin, P., Gelencsér, A., Dabek-Zlotorzynska, E., Kiss, G., Hertkorn, N., Harir, M., Hong, Y., and Gebefügi, I.: Analysis of the Unresolved Organic Fraction in Atmospheric Aerosols with Ultrahigh-Resolution Mass Spectrometry and Nuclear Magnetic Resonance Spectroscopy: Organosulfates As
Photochemical Smog Constituents, Anal. Chem., 82, 8017-8026, https://doi.org/10.1021/ac101444r, 2010.

Shi, Z., Vu, T., Kotthaus, S., Harrison, R. M., Grimmond, S., Yue, S., Zhu, T., Lee, J., Han, Y., Demuzere, M., Dunmore, R. E., Ren, L., Liu, D., Wang, Y., Wild, O., Allan, J., Acton, W. J., Barlow, J., Barratt, B., Beddows, D., Bloss, W. J., Calzolai, G., Carruthers, D., Carslaw, D. C., Chan, Q., Chatzidiakou, L., Chen, Y., Crilley, L., Coe, H., Dai, T., Doherty, R., Duan, F., Fu, P., Ge, B., Ge, M., Guan, D., Hamilton, J. F., He, K., Heal, M., Heard, D., Hewitt, C. N., Hollaway, M., Hu, M., Ji, D., Jiang, X., Jones, R., Kalberer, M., Kelly, F. J., Kramer, L., Langford, B., Lin, C., Lewis, A. C., Li, J., Li, W., Liu, H., Liu, J., Loh, M., Lu, K., Lucarelli, F., Mann, G., McFiggans, G., Miller, M. R., Mills, G., Monk, P., Nemitz, E., O’Connor, F., Ouyang, B., Palmer, P. I., Percival, C., Popoola, O., Reeves, C., Rickard, A. R., Shao, L., Shi, G., Spracklen, D., Stevenson, D., Sun, Y., Sun, Z., Tao, S., Tong, S., Wang, Q., Wang, W., Wang, X., Wang, X., Wang, Z., Wei, L., Whalley, L., Wu, X., Wu, Z., Xie, P., Yang, F., Zhang, Q., Zhang, Y., Zhang, Y., and Zheng, M.: Introduction to the special issue "In-depth study of air pollution sources and processes within Beijing and its surrounding region (APHH-Beijing)", Atmos. Chem. Phys., 19, 7519-7546, https://doi.org/10.5194/acp19-7519-2019, 2019.

Smith, S. J., Pitcher, H., and Wigley, T. M. L.: Global and regional anthropogenic sulfur dioxide emissions, Global Planet. Change, 29, 99-119, https://doi.org/10.1016/S09218181(00)00057-6, 2001.

Song, J., Li, M., Fan, X., Zou, C., Zhu, M., Jiang, B., Yu, Z., Jia, W., Liao, Y., and Peng, P.: Molecular Characterization of Waterand Methanol-Soluble Organic Compounds Emitted from Residential Coal Combustion Using Ultrahigh-Resolution Electrospray Ionization Fourier Transform Ion Cyclotron Resonance Mass Spectrometry, Environ. Sci. Technol., 53, 13607-13617, https://doi.org/10.1021/acs.est.9b04331, 2019.

Song, Y., Tang, X., Xie, S., Zhang, Y., Wei, Y., Zhang, M., Zeng, L., and Lu, S.: Source apportionment of $\mathrm{PM}_{2.5}$ in Beijing in 2004, J. Hazard. Mater., 146, 124-130, https://doi.org/10.1016/j.jhazmat.2006.11.058, 2007.

Steimer, S. and Kalberer, M.: APHH: Direct infusion ultra-high resolution mass spectrometry measurements made at the IAPBeijing site during the summer and winter campaigns, Centre for Environmental Data Analysis, available at: https://catalogue. ceda.ac.uk/uuid/680ebdcb83c244fdb9d069e2f8952812, last access: 20 July 2020.

Surratt, J. D., Gómez-González, Y., Chan, A. W. H., Vermeylen, R., Shahgholi, M., Kleindienst, T. E., Edney, E. O., Offenberg, J. H., Lewandowski, M., Jaoui, M., Maenhaut, W., Claeys, M., Flagan, R. C., and Seinfeld, J. H.: Organosulfate Formation in Biogenic Secondary Organic Aerosol, J. Phys. Chem. A, 112, 8345-8378, https://doi.org/10.1021/jp802310p, 2008.

Tao, S., Lu, X., Levac, N., Bateman, A. P., Nguyen, T. B., Bones, D. L., Nizkorodov, S. A., Laskin, J., Laskin, A., and Yang, X.: Molecular Characterization of Organosulfates in Organic Aerosols from Shanghai and Los Angeles Urban Areas by Nanospray-Desorption Electrospray Ionization High-Resolution Mass Spectrometry, Environ. Sci. Technol., 48, 10993-11001, https://doi.org/10.1021/es5024674, 2014.

Tong, H., Kourtchev, I., Pant, P., Keyte, I. J., O’Connor, I. P., Wenger, J. C., Pope, F. D., Harrison, R. M., and 
Kalberer, M.: Molecular composition of organic aerosols at urban background and road tunnel sites using ultra-high resolution mass spectrometry, Faraday Discuss., 189, 51-68, https://doi.org/10.1039/C5FD00206K, 2016.

Valle-Hernández, B. L., Mugica-Álvarez, V., Salinas-Talavera, E., Amador-Muñoz, O., Murillo-Tovar, M. A., Villalobos-Pietrini, R., and De Vizcaya-Ruíz, A.: Temporal variation of nitropolycyclic aromatic hydrocarbons in $\mathrm{PM}_{10}$ and $\mathrm{PM}_{2.5}$ collected in Northern Mexico City, Sci. Total Environ., 408, 5429-5438, https://doi.org/10.1016/j.scitotenv.2010.07.065, 2010.

Walgraeve, C., Demeestere, K., Dewulf, J., Zimmermann, R., and Van Langenhove, H.: Oxygenated polycyclic aromatic hydrocarbons in atmospheric particulate matter: Molecular characterization and occurrence, Atmos. Environ., 44, 1831-1846, https://doi.org/10.1016/j.atmosenv.2009.12.004, 2010.

Wang, H., Tian, M., Li, X., Chang, Q., Cao, J., Yang, F., Ma, Y., and He, K.: Chemical Composition and Light Extinction Contribution of $\mathrm{PM}_{2.5}$ in Urban Beijing for a 1-Year Period, Aerosol Air Qual. Res., 15, 2200-2211, https://doi.org/10.4209/aaqr.2015.04.0257, 2015.

Wang, K., Zhang, Y., Huang, R.-J., Cao, J., and Hoffmann, T.: UHPLC-Orbitrap mass spectrometric characterization of organic aerosol from a central European city (Mainz, Germany) and a Chinese megacity (Beijing), Atmos. Environ., 189, 22-29, https://doi.org/10.1016/j.atmosenv.2018.06.036, 2018.

Wang, K., Zhang, Y., Huang, R.-J., Wang, M., Ni, H., Kampf, C. J., Cheng, Y., Bilde, M., Glasius, M., and Hoffmann, T.: Molecular Characterization and Source Identification of Atmospheric Particulate Organosulfates Using Ultrahigh Resolution Mass Spectrometry, Environ. Sci. Technol., 53, 6192-6202, https://doi.org/10.1021/acs.est.9b02628, 2019.

Wang, X., Hayeck, N., Brüggemann, M., Yao, L., Chen, H., Zhang, C., Emmelin, C., Chen, J., George, C., and Wang, L.: Chemical Characteristics of Organic Aerosols in Shanghai: A Study by Ultrahigh-Performance Liquid Chromatography Coupled With Orbitrap Mass Spectrometry, J. Geophys. Res.-Atmos., 122, 11703-11722, https://doi.org/10.1002/2017JD026930, 2017a.

Wang, X., Gu, R., Wang, L., Xu, W., Zhang, Y., Chen, B., Li, W., Xue, L., Chen, J., and Wang, W.: Emissions of fine particulate nitrated phenols from the burning of five common types of biomass, Environ. Pollut., 230, 405-412, https://doi.org/10.1016/j.envpol.2017.06.072, 2017b.

Wang, Y., Zhuang, G., Sun, Y., and An, Z.: The variation of characteristics and formation mechanisms of aerosols in dust, haze, and clear days in Beijing, Atmos. Environ., 40, 6579-6591, https://doi.org/10.1016/j.atmosenv.2006.05.066, 2006.

World Health Organization: Ambient air pollution: a global assessment of exposure and burden of disease, World Health Organization, available at: https://apps.who.int/iris/handle/10665/250141, 2016.

Worton, D. R., Isaacman, G., Gentner, D. R., Dallmann, T. R., Chan, A. W. H., Ruehl, C., Kirchstetter, T. W., Wilson, K. R., Harley, R. A., and Goldstein, A. H.: Lubricating Oil Dominates Primary Organic Aerosol Emissions from Motor Vehicles, Environ. Sci. Technol., 48, 3698-3706, https://doi.org/10.1021/es405375j, 2014.

Wozniak, A. S., Bauer, J. E., Sleighter, R. L., Dickhut, R. M., and Hatcher, P. G.: Technical Note: Molecular characterization of aerosol-derived water soluble organic carbon using ultrahigh res- olution electrospray ionization Fourier transform ion cyclotron resonance mass spectrometry, Atmos. Chem. Phys., 8, 50995111, https://doi.org/10.5194/acp-8-5099-2008, 2008.

Yassine, M. M., Harir, M., Dabek-Zlotorzynska, E., and SchmittKopplin, P.: Structural characterization of organic aerosol using Fourier transform ion cyclotron resonance mass spectrometry: Aromaticity equivalent approach, Rapid Commun. Mass Sp., 28, 2445-2454, https://doi.org/10.1002/rcm.7038, 2014.

Yu, L., Wang, G., Zhang, R., Zhang, L., Song, Y., Wu, B., Li, X., An, K., and Chu, J.: Characterization and Source Apportionment of $\mathrm{PM}_{2.5}$ in an Urban Environment in Beijing, Aerosol Air Qual. Res., 13, 574-583, https://doi.org/10.4209/aaqr.2012.07.0192, 2013.

Zhang, H., Wang, S., Hao, J., Wang, X., Wang, S., Chai, F., and Li, M.: Air pollution and control action in Beijing, J. Clean. Prod., 112, 1519-1527, https://doi.org/10.1016/j.jclepro.2015.04.092, 2016.

Zhang, J., Dransfield, T., and Donahue, N. M.: On the Mechanism for Nitrate Formation via the Peroxy Radical + NO Reaction, J. Phys. Chem. A, 108, 9082-9095, https://doi.org/10.1021/jp048096x, 2004.

Zhang, J., Ouyang, Z., Miao, H., and Wang, X.: Ambient air quality trends and driving factor analysis in Beijing, 1983-2007, J. Environ. Sci., 23, 2019-2028, https://doi.org/10.1016/S10010742(10)60667-5, 2011.

Zhang, R., Jing, J., Tao, J., Hsu, S.-C., Wang, G., Cao, J., Lee, C. S. L., Zhu, L., Chen, Z., Zhao, Y., and Shen, Z.: Chemical characterization and source apportionment of $\mathrm{PM}_{2.5}$ in Beijing: seasonal perspective, Atmos. Chem. Phys., 13, 7053-7074, https://doi.org/10.5194/acp-13-7053-2013, 2013.

Zhang, Y., Chen, J., Yang, H., Li, R., and Yu, Q.: Seasonal variation and potential source regions of $\mathrm{PM}_{2.5}$-bound PAHs in the megacity Beijing, China: Impact of regional transport, Environ. Pollut., 231, 329-338, https://doi.org/10.1016/j.envpol.2017.08.025, 2017a.

Zhang, Z., Wang, W., Cheng, M., Liu, S., Xu, J., He, Y., and Meng, F.: The contribution of residential coal combustion to $\mathrm{PM}_{2.5}$ pollution over China's Beijing-TianjinHebei region in winter, Atmos. Environ., 159, 147-161, https://doi.org/10.1016/j.atmosenv.2017.03.054, 2017b.

Zhou, Y., Cheng, S., Chen, D., Lang, J., Wang, G., Xu, T., Wang, X., and Yao, S.: Temporal and Spatial Characteristics of Ambient Air Quality in Beijing, China, Aerosol Air Qual. Res., 15, 18681880, https://doi.org/10.4209/aaqr.2014.11.0306, 2015.

Zielinski, A. T., Kourtchev, I., Bortolini, C., Fuller, S. J., Giorio, C., Popoola, O. A. M., Bogialli, S., Tapparo, A., Jones, R. L., and Kalberer, M.: A new processing scheme for ultra-high resolution direct infusion mass spectrometry data, Atmos. Environ., 178, 129-139, https://doi.org/10.1016/j.atmosenv.2018.01.034, 2018.

Zíková, N., Wang, Y., Yang, F., Li, X., Tian, M., and Hopke, P. K.: On the source contribution to Beijing $\mathrm{PM}_{2.5}$ concentrations, Atmos. Environ., 134, 84-95, https://doi.org/10.1016/j.atmosenv.2016.03.047, 2016. 